\title{
Applying three distinct metrics to measure people's perceptions of resilience
}

\author{
$\underline{\text { Takuro Uehara }}^{1}, \underline{\text { Takahiro Tsuge }}^{2}$ and $\underline{\text { Avumi Onuma }}^{3}$
}

\begin{abstract}
Resilience management is gaining support as resilience studies proliferate. Quantification of resilience could help decision makers understand the complex dynamics of resilience and adopt resilience management. However, most quantifications have focused on resilience as an attribute of social-ecological systems, such as thresholds and safe operating spaces. Although informative for planning and implementing effective resilience management, they do not inform decision makers if people accept and support this management. Therefore, it is necessary to understand how people perceive resilience. We applied three metrics to measure how people perceive resilience: (1) an economic valuation of resilience, (2) motivations behind valuing resilience, and (3) the relative importance of resilience compared with other ecosystem services. We adopted coral reef ecosystems in Okinawa, Japan for our analysis. Coral reef ecosystems, which are rich in marine genetic resources (hotspots), have become endangered because of increasing anthropocentric pressures, and resilience is becoming an accepted method in coral reef ecosystem management. Our study revealed that an ex-ante willingness to pay (WTP) for expected benefits from a resilience management program ranged from 3439 to 5663 JPY for mean WTP and from 1615 to 2579 JPY for median WTP (cf. $100 \mathrm{JPY}=0.891 \mathrm{USD}$ in 2017). Primary motivations, i.e., human values, underlying the valuation of resilience were conservation and self-transcendence, which overlap with some ecosystem services such as culture, bequest, education, coastal protection, sanitation, and habitat. Resilience is highly important compared with the other 10 coral reef ecosystem services. These findings could help decision makers plan and implement an effective, acceptable, and supported resilience management program.
\end{abstract}

Key Words: best-worst scaling; coral reef ecosystems; ecosystem services; human value theory; resilience; willingness to pay

\section{INTRODUCTION}

Along with the advancement of resilience studies, resilience has gained support as a management approach to sustainable socialecological systems (SESs), and it has influenced managers across terrestrial, freshwater, and marine systems (Anderies et al. 2006, Anthony et al. 2015). After the concept of resilience was introduced as an attribute of ecosystems (Holling 1973), it has also been studied in SESs (Carpenter et al. 2001, Walker et al. 2004, Walker and Salt 2006) because of its significant influence on their system dynamics. The understanding and maintenance of resilience are critical because it preserves ecosystem services, from which we benefit (Biggs et al. 2015). When SESs are resilient enough against external shocks such as anthropocentric pressures, systems can stay in the same domain of attraction and provide the same ecosystem services. Otherwise, shocks cause a regime shift in the systems, leaving them in another domain of attraction, which no longer maintains the same ecosystem services. For example, while healthy coral reef ecosystems provide rich ecosystem services (Moberg and Folke 1999), external shocks such as extra nutrients and fishing pressure could make insufficiently resilient coral reefs surpass their thresholds, turning them into rocky seascapes (Bellwood et al. 2004). Rocks provide fewer ecosystem services (Bellwood et al. 2004).

Although theoretical development of the ideas and general principles of resilience is the sine qua non of its further development (Berkes and Folke 1998, Folke et al. 2002, Anderies et al. 2006, Walker and Salt 2006, Uehara 2013, Biggs et al. 2015), bridging gaps between science, policy, and management, in particular, suggest the need for further quantitative studies to measure and assess resilience (Quinlan et al. 2015, Baho et al. 2017). Quantitative assessment and measurement, simplified and contextual information about complexity (Quinlan et al. 2015), could expedite managers' adoption of resilience in practice.
Literature about the quantitative assessment and measurement of resilience has grown (Quinlan et al. 2015, Baho et al. 2017). In addition to relatively conventional measurements of resilience such as minimum viable population (Traill et al. 2007), others include measuring thresholds, regime shifts, and safe operating spaces, employing various methods such as indicators, computer models, and statistical techniques (Rockström et al. 2009, Uehara 2013, Karr et al. 2015, Quinlan et al. 2015, Norström et al. 2016, Cumming and Peterson 2017).

Although such quantifications help managers, policy makers, and stakeholders make informed decisions (Erwin et al. 2010), current quantifications generally describe resilience as an attribute of SESs. That is, quantifications of how people perceive resilience have been lacking. However, resilience management needs not only to be effective but also accepted and supported. Resilience is neither absolute good nor something that always needs to be enhanced. Assessment of a system's resilience requires specifying system configurations and disturbances "of interest" (Carpenter et al. 2001). For example, resilience management that keeps an ecosystem in an undesirable state, e.g., rocky seascapes providing few ecosystem services, is unacceptable. Resilience management that is prohibitively costly relative to its benefit also should not take place. The way resilience is enhanced, e.g., using either a topdown or bottom-up approach, could also influence its outcome.

At least three overlapping but distinct aspects of our perception of resilience can be measured as resilience management inputs: the economic valuation of resilience, motivations behind valuing resilience, and the relative importance of resilience compared to other ecosystem services. Despite the potential efficacies of adopting protected areas as an example of resilience management, such programs are severely underfunded (Farnsworth et al. 2015, Voltaire 2017). This concerns not only protected areas but also biodiversity funding at a global level (Sumaila et al. 2017). Lack 
of funding is related to an underappreciation of the benefits of protected areas (Baral et al. 2008, Bartkowski et al. 2015, Voltaire 2017). It is more easily understood by management because the concept of resilience is more concrete than that of biodiversity or a vague notion of naturalness (Farnsworth et al. 2015), so that its value can be directly fed into management. Knowing the motivations underlying valuing resilience, or when and why people appreciate resilience, can lead to better resilience efforts. People are more likely to respond positively to opportunities when they dovetail with their motivations, or their high-priority value types or value domains (Schwartz 1996). Therefore, it helps decision makers anticipate how and why people respond to certain management practices, making resilience management more acceptable to stakeholders. Nevertheless, understanding the motivations behind certain conservation practices remains a fundamental challenge (Hicks et al. 2015). Last, the relative importance of resilience vis-a-vis other ecosystem services is critical in practice, because introducing resilience management may have trade-offs or synergies with other ecosystem services. For example, introducing resilience management could restrict fishing, which would directly impact fishermen's income.

The purpose of this paper is to add to studies of people's perceptions of resilience while looking at the implications behind resilience management. Using coral reef ecosystems in Okinawa, Japan, we measured three aspects of people's perceptions of resilience. Although coral reef ecosystems are rich in biodiversity and are an essential source of genetic resources (Arrieta et al. 2010), they are in danger (Moberg 2017). The value of resilience was measured by an ex ante WTP for a marginal increase in resilience (Baumgärtner and Strunz 2014). The motivations behind valuing resilience were measured using Schwartz's human value theory (Schwartz 1996, Hicks et al. 2015). The relative importance of resilience in the Okinawa reef was then compared to other coral reef ecosystem services.

\section{METHODS}

This section explains the study site, the methods used to measure the three metrics, and the justifications for their inclusion. For data analysis, we used a package by Nakatani, Aizaki, and Sato (https://cran.r-project.org/web/packages/DCchoice/citation.html) run on $\mathrm{R}$ (Version 3.3.2 for Windows [64 bit]) by the $\mathrm{R}$ foundation (https://www.r-project.org/), and STATA (Version 14.2) by StataCorp LP (http://www.stata.com).

\section{Study site: coral reef ecosystems in Okinawa, Japan}

We chose to study coral reef ecosystems in Okinawa, Japan. There are three primary reasons to investigate resilience management in coral reef ecosystems. First, they are rich in genetic biodiversity. Protecting genetic diversity is one of the Aichi Biodiversity Targets (Target 13; Convention on Biological Diversity 2010). Compared with terrestrial genetic resources, marine genetic resources (MGRs) have become a growing source of biotechnological and business opportunities (Arrieta et al. 2010). Patents associated with the genes of marine organisms are rapidly increasing (Arrieta et al. 2010). Among marine ecosystems, coral reef ecosystems are considered MGR biodiversity hotspots (Arrieta et al. 2010).

Second, coral reef ecosystems worldwide are in serious decline because of various stressors, including anthropocentric ones
(Bellwood et al. 2004, Arrieta et al. 2010, Anthony et al. 2015). Proper management of coral reef ecosystems, therefore, is urgently needed. Third, as the understanding of coral reef ecosystems advances, resilience management is gaining support from coral reef ecosystem management (Bellwood et al. 2004, Nyström et al. 2008, Hughes et al. 2010, Anthony et al. 2015, Karr et al. 2015, Mellin et al. 2016). This is a logical extension of current ecosystem-based coral reef ecosystem management practices (Hughes et al. 2010). Coral reef ecosystems are complex and dynamic systems that exhibit nonlinear behavior, critical tipping points (thresholds), hysteresis, irreversibility, and multiple stable states (Nyström et al. 2008, Hughes et al. 2010). The resilience concept sheds light on these attributes.

Okinawa, in the southernmost region of Japan, contains most of Japan's coral reefs. These ecosystems are rich in genetic resources, with 33,629 described species accounting for $14.6 \%$ of all marine species in the world. Furthermore, more than $70 \%$ of Japan's marine life remains undescribed (Fujikura et al. 2010). However, Japan's coral reef ecosystems have deteriorated because of various anthropocentric pressures, e.g., red soil from land areas, the crown-of-thorns starfish (Acanthaster planci), typhoons, and rising seawater temperatures (Ministry of the Environment, Government of Japan 2017).

Conservation of coral reef ecosystems is an important policy agenda for Japan. The Action Plan to Conserve Coral Reef Ecosystems (Ministry of the Environment, Government of Japan 2017) was adopted to preserve coral reef ecosystems, as described in the National Biodiversity Strategy of Japan 2012-2020 (cabinet decision on 28 September 2012) and the Basic Plan on Ocean Policy (cabinet decision on 26 April 2013). These programs are expected to help in achieving the Aichi Target (Ministry of the Environment, Government of Japan 2017).

\section{Data collection}

We prepared questionnaires to measure how people perceive resilience, i.e., economic valuation, motivations behind valuing resilience, and the relative importance of resilience. An online survey was conducted from 26 October through 1 November 2017. Because we expected different responses from residents inside and outside Okinawa, i.e., the four main Japanese islands, we collected 605 surveys from 605 Okinawa residents and 566 from individuals living outside Okinawa. The survey was conducted in Japanese.

As shown in Table 1, we prepared three types of questionnaires, each combining two sets of questions. Respondents were also asked basic details regarding gender, income, age, and other items. A respondent was presented only one of the three types of questions because asking the respondents about both motivations and relative importance required them answering too many questions. Therefore, the respondents were asked questions about the economic value of resilience, with only motivations or relative importance, to reduce the respondents' burden and maintain the quality of the answers.

The second type of question asked about the relative importance of resilience after questioning the economic value of resilience; the third type of question asked about the economic value of resilience after questioning the relative importance of resilience (Table 1). We had expected that detailed descriptions of the 
Table 1. Three types of questionnaires, with their sample sizes.

\begin{tabular}{llll}
\hline \hline & Type 1 & Type 2 \\
\hline $1^{\text {st }}$ set of questions & Value of resilience & Value of resilience & Type 3 \\
$2^{\text {nd }}$ set of questions & Motivations behind valuing resilience & Relative importance of resilience & Value of resilience \\
Sample size & Okinawa, 278; & Okinawa, 144; & Okinawa, 144; \\
& Outside, 260 & Outside, 214 & Outside, 131 \\
\hline
\end{tabular}

benefits of resilience in the valuation of resilience would affect results regarding the relative importance of resilience. We explained the benefits to respondents in the economic valuation (see "The contingent valuation method and scenario design" section) and the relative importance of resilience (see "Measuring the relative importance of resilience to other ecosystem services" section).

To check and improve the questionnaires before the primary survey, we conducted an online pretest from 29 September to 4 October 2017 using 120 respondents each from inside and outside Okinawa. Related descriptive statistics are available as supplementary information in Appendix 1. Critical components of the questions, for each measurement, are addressed below.

\section{Measuring the economic value of resilience}

The economic value of resilience

Resilience has an insurance value, with which a system can remain in the desired state and maintain the provisioning of ecosystem services in the face of external shocks (Perrings 1995, Holling et al. 2002, Baumgärtner 2007, Rönnbäck et al. 2007, Mäler 2008). Insurance value is one of the two primary types of economic value of ecosystems, the other is output value (TEEB 2010). Insurance value can be measured as the aggregate value of foregone output, caused by the loss of resilience (Perrings 1995).

Although resilience value has been well-accepted, attempts to measure it have been limited. On the one hand, some authors believe that measuring the economic value of resilience is difficult because it involves complex, nonmarginal behaviors of SESs (Pritchard et al. 2000, Limburg et al. 2002, TEEB 2010). On the other hand, measuring forms of resilience that stabilize ecosystems (repositories of genetic information) is one of five new directions in environmental economics (Freeman et al. 2014). Therefore, designing and implementing economic valuations should be conducted with great care.

There are two ways to measure the economic value of resilience. One method treats resilience as a type of stock similar to others, e.g., man-made, natural, and human, to calculate inclusive wealth (Arrow et al. 2003, Mäler 2008, Mäler and Li 2010, Walker et al. 2010, Pearson et al. 2013). Resilience is measured by the distance of a stock, e.g., a healthy reef, from a threshold level that causes it to change into a different form, e.g., rock, thereby altering the ecosystem services (Pearson et al. 2013). As an example, this measurement was applied to the Goulburn-Broken Catchment in Australia (Pearson et al. 2013).

A second method is to measure the maximum ex ante WTP for a marginal increase in resilience (Baumgärtner and Strunz 2014). The value of resilience has been often referred to metaphorically. Baumgärtner and Strunz (2014) mathematically demonstrated that the economic value of resilience comprises two additive components: the sum of an expected increase in income due to a marginal increase in resilience and the insurance value of a marginal increase in resilience. WTP includes not only the insurance value but also the expected increase in income derived from a marginal increase in resilience (Baumgärtner and Strunz 2014).

Our study chose to measure an ex ante WTP because our interest lies in how people value resilience. To our knowledge, no empirical study has yet applied this approach. Baumgärtner and Strunz (2014) defined the economic value of resilience with a mathematical, ecological-economic model. The economic value $V$ of resilience is defined as the maximum ex ante WTP per unit for a marginal increase of $\Delta R$ in the level of resilience $R$ :

$$
V(R):=\lim _{\Delta R \rightarrow 0} \frac{W T P(\Delta R)}{\Delta R}
$$

where WTP is defined as

$$
E_{R}[u(y)]=E_{R+\Delta R}[u(y-W T P(\Delta R))]
$$

$E[u()$.$] is an ecosystem user's expected utility, and y$ is the user's income. Maximum WTP is the amount when the user is indifferent to marginal increases in the level of resilience $R$. This is an ex ante measure because the user is not certain about the ecosystem's later status. $\operatorname{WTP}(\triangle R)$ is the Hicksian compensating variation for a finite change of $\Delta R$ in the level of resilience (Baumgärtner and Strunz 2014, Freeman et al. 2014).

The contingent valuation method and scenario design

We adopted a contingent valuation method (CVM; Freeman et al. 2014, Boyle 2017) to measure $W T P(\Delta R)$, as in Equation (2). CVM presents a hypothetical scenario that could affect the respondents' utility and asks if they are willing to pay for the project in the scenario. Because of its hypothetical nature, it might face various biases, resulting in a biased estimate. Additionally, since the benefits of resilience are closely associated with the complexity of ecological systems, valuations need to be ecologically sound to make the findings as practical as possible (Pritchard et al. 2000, Limburg et al. 2002). Therefore, in addition to carefully designing and conducting the survey by following standard CVM guidelines (Boyle 2017, Freeman et al. 2014), we paid particular attention to the ecological soundness of the scenario as described below.

To make the scenario as relevant and as realistic as possible to science and policy, e.g., coral reef science, resilience concepts, and economics, we conducted interviews with experts and policy 
makers and undertook a literature review. We presented respondents with the following hypothetical scenario (see Appendix 2 for further details).

Establish a 1-ha $(100 \mathrm{~m} \times 100 \mathrm{~m})$ marine-protected area $(\mathrm{MPA})$ in a coral reef ecosystem in Okinawa that enhances the resilience of the ecosystem and prevents it from losing rich genetic resources. Although an MPA could make additional impacts, we assume that there is no impact other than resilience and genetic resources.

We chose MPAs as a resilience management measure because their effectiveness is well accepted in coral reef ecosystem management. For example, a study based on a 20-year time series for Australia's Great Barrier Reef revealed that MPAs increased resilience (Mellin et al. 2016). The size of MPA should reflect various aspects including ecological and socioeconomic validity. We discussed the relevance with experts. Although 1 ha could be too small to cover a single coral reef ecosystem, it is not unrealistic to set 1-ha MPA after various aspects considered. We then articulated the benefits of MPAs.

Enhancing coral reefs' resilience lowers the probability of losing the ecosystem's structure and functions. Maintaining it would provide richer genetic resources than other states, e.g., macroalgae, sea urchin barren, or rocky, where coral reef ecosystems are lost.

These benefits correspond to two components of the economic value of resilience (Baumgärtner and Strunz 2014). Although MPAs could change other ecosystem services, this scenario assumes that other ecosystem services remain the same, focusing on the two aspects of resilience value. According to experts' opinions, this assumption is at least not unrealistic. Because gene sampling requires only a small amount of biomass, it may not threaten biodiversity (Arrieta et al. 2010).

Because uncertainty is an essential characteristic of resilience and the discovery of genetic resources, we added two caveats regarding MPA benefits. Discovery of genetic resources and MPA's efficacy in enhancing resilience are uncertain. In our questionnaires, by following the state-contingent approach (Perry and Shankar 2017), we eschewed presenting any statistical probabilities regarding outcomes. This contrasts with other studies (e.g., Rolfe and Windle 2015). The problem with resilience-based ecosystem management is not the risk associated with the probability of known outcomes but its fundamental uncertainty (Perrings 1995). Perrings (1995) argued that the insurance value of resilience reduces uncertainty, rather than risk. Respondents answered the questionnaires based on their subjective understanding of uncertainty or subjective probabilities, which reflected their beliefs, given the information available, about the future state of the ecosystem (Perry and Shankar 2017). Because it is quite difficult, if not impossible, for coral reef science to explain every aspect of coral reefs' ecosystems (Kumar 2010), it is critical for policy makers to know if respondents support scenarios under a condition of radical uncertainty. In other words, policy makers cannot assure the public with absolute certainty (or known probabilities) what benefits can be obtained from resilience.

Before respondents answered the questionnaire about WTP, they took a quiz about their understanding of the scenario and their benefits. Respondents who answered incorrectly were asked to reread the scenario again.
A double-bound, dichotomous choice method was used to elicit WTP, which is less susceptible to biases compared with other methods (Mitchell and Carson 1989). Respondents were asked if they would be willing to pay asked amounts (a one-time payment, the benefits of which were assumed to last for 10 years) to establish and maintain the MPA. We proposed seven different bid amounts $(100,300,1000,3000,5000,10,000$, and 20,000 JPY). Five different combinations of bid values (in JPY) were used (Initial; Lower; Upper): 1. (300; 100; 1000), 2. (1,000; 300; 3,000), 3. (3000; $1000 ; 5000)$, 4. $(5000 ; 3000 ; 10,000)$, and 5. $(10,000 ; 5000 ; 20,000$; cf. $100 \mathrm{JPY}=\mathrm{US} \$ 0.89$ in 2017). Each respondent was presented with one of the seven bid amounts at random (e.g., 300 JPY). If this bid was declined, the next lowest bid (here, 100 JPY) was presented. Conversely, if the bid was accepted, the next higher bid (here, 1000 JPY) was presented. The payment scale was determined based on previous studies of WTP estimates for Japanese coral reef ecosystems (Fujita 2003, Oh 2004, Shinbo 2007, Tamura 2009) and also validated in the online pretest.

We adopted the log-logistic model (Aizaki et al. 2015) to estimate median and mean WTP. Their confidence intervals were calculated using the Krinsky and Robb method (Krinsky and Robb 1986, Aizaki et al. 2015). In addition to the questions for WTP estimation, we asked the respondents their reasons for bidding.

\section{Identifying values that underlie resilience}

Although WTP measures a particular aspect of resilience values, it does not capture its underlying reasons and motivations (Flores 2017, Segerson 2017). In the former, the resulting improvement is called an assigned value, e.g., a restoration project. The latter, which motivates people to support the change, is called a held value (Brown 1984, Uehara et al. 2018). Held values explain why people take certain actions and understanding their motivations is critical for two reasons. First, understanding motivations helps decision makers predict how people respond to resilience management, which could change ecosystem services. Second, it could also help decision makers situate resilience management in a broader context. Environmental issues are just one of many concerns in people's everyday lives, where held values or motivations (not just environmental issues) guide every action (Schwartz 1992). Therefore, it could help decision makers predict how people respond to resilience management while considering issues other than ecosystem services. Environmental issues are not independent of people's everyday lives.

We used the Schwartz's human value theory (HVT; Schwartz 1996) from social psychology, to identify the human values underlying motivations associated with resilience. HVT contains a circular structure of 10 personal, life values that explain the motivational basis of attitudes and behavior (Schwartz 2012). They are benevolence, universalism, self-direction, stimulation, hedonism, achievement, power, security, tradition, and conformity (Schwartz 2012). The circular structure captures the conflicts and compatibility among the 10 values (Schwartz 2012). Attitudes and behavior are guided by trade-offs or the relative importance of competing values, so that differences in value priorities explain differences in attitudes and behavior (Schwartz 1996).

We asked respondents to rank the motivations that we had prepared. Instead of using the Schwartz value survey (SVS), 
Table 2. Underlying motivations categorized into Schwartz value domains and types.

\begin{tabular}{lll}
\hline \hline Schwartz value domain & $\begin{array}{l}\text { Schwartz value } \\
\text { type }\end{array}$ & Underlying motivations \\
\hline 1. Openness to change & $\begin{array}{l}\text { Self-direction } \\
\text { Stimulation }\end{array}$ & $\begin{array}{l}\text { Exploring new sources of income. Exploring new genetic resources. } \\
\text { The novelty of resilience thinking. Challenge to uncertainty. } \\
\text { The pure pleasure of a discovery. }\end{array}$ \\
$\begin{array}{ll}\text { 2. Openness to change/Self-enhancement } \\
\text { 3. Self-enhancement }\end{array}$ & $\begin{array}{l}\text { Hedonism } \\
\text { Achievement }\end{array}$ & $\begin{array}{l}\text { The sense of accomplishment obtained by providing for people, community, family, } \\
\text { and oneself. }\end{array}$ \\
& Power & Control over nature. Harnessing nature. \\
4. Self-transcendence & Benevolence & For family and neighbors. \\
& Universalism & For human beings and for nature. \\
5. Conservation & Conformity & Behaving respectfully. \\
& Security & Minimizing environmental impacts. \\
& Tradition & Respect for local customs and traditions. \\
\hline
\end{tabular}

which was time consuming and took up too much space in the questionnaires (Lindeman and Verkasalo 2005), we adopted a best-worst scaling (BWS) approach (Louviere et al. 2015). A BWS takes less respondent time than the SVS but still reproduces Schwartz's theoretical value structure (Lee et al. 2008).

We prepared motivations using the 10 value types (Table 2 ). These motivations adopted the underlying ecosystem service motivations by Hicks et al. (2015) as a base, which identified human values underlying coral reef ecosystem services in Kenya, Tanzania, Madagascar, and Seychelles. The focus groups in Hicks et al. (2015) identified 54 motivations, categorized into Schwartz value types and domains. We tailored these motivations for three reasons. First, Hicks et al. (2015) did not cover resilience. Second, the motivations may not be comprehensive because they are a collection of statements by fishermen, fish processors, and traders. Third, we used an online survey, rather than the in-depth interviews and focus groups adopted by Hicks et al. (2015). Given these differences, we simplified the motivations, so that the respondents could comprehend them without additional explanation. To cover motivations related to resilience and genetic resources, we referred to a general marine ecosystem services classification by Hattam et al. (2015). The first author of this paper created a draft and the second author checked if it was consistent and understandable.

We narrowed down the respondents for this analysis by asking if they valued resilience, irrespective of their answers to bids presented in the economic valuation of resilience. Some respondents may have declined bids in the CVM scenario but still understood the importance of resilience.

We presented the underlying motivations corresponding to each of the Schwartz value domains in five categories, four value domains, and on an overlapping domain (Table 2). Because the underlying motivations are concrete examples of each domain, they are easier to understand than the domain names. This followed the suggestion by Hicks et al. (2015) that ecosystem service research should focus on value domains rather than value types. In the BWS, respondents were asked several times, with different combinations of items selected from all items, to identify the most and the least appropriate motivations associated with resilience. With five categories of motivations, five sets of choices were presented, each of which comprised a mutually exclusive combination of four (of five) categories of motivations (Appendix
3). This design conforms to the balanced, incomplete block design in Louviere et al. (2015). Respondents rated the motivations after learning about resilience and its benefits, described in the survey, to economically value resilience.

To analyze the results, we adopted a counting approach (Aizaki et al. 2015) and used the following Standardized $\mathrm{BW}_{i}$.

$$
\text { Standardized } \mathrm{BW}_{i}=\frac{\Sigma_{n} B_{i n}-\Sigma_{n} W_{i n}}{N r}
$$

Where $B_{i n}$ and $W_{\text {in }}$ are the number of times that item $i$ is selected as the best and the worst of all the questions by respondent $n . r$ is the number of times that item $i$ appears in all questions. $N$ is the number of respondents. The value of Standardized BW $\mathrm{BW}_{i}$ shows the relative importance of item $i$. Standardized $\mathrm{BW}_{i}$ is zero either when respondents select item $i$ as the best as often as they select it as the worst, or when they select it as neither the best nor the worst. Standardized $\mathrm{BW}_{i}$ can take a value of minus 1 through 1 , with increments of 0.25 .

To explore respondents' characteristics behind values associated with resilience, we applied an ordered logit model for ordinal variables (Long and Freese 2014). Ordered logit models regress Standardized $\mathrm{BW}_{i}(i$ is the item associated with resilience) on respondents' socioeconomic characteristics and estimate the vector of coefficient $\beta$ in the following probability of observing outcome $l$ (i.e., Standardized $\mathrm{BW}_{i}$ ) for respondent $j$ (STATA 2017)

$$
\begin{aligned}
& \operatorname{Pr}\left(\text { outcome }_{j}=l\right) \\
& =\operatorname{Pr}\left(K_{\mathrm{l}-1}<X_{j} \beta+u_{j} \leqslant k_{l}\right) \\
& =\frac{1}{1+e^{-k_{l}+X_{j} \beta}}-\frac{1}{1+e^{-k_{1-1}+X_{j} \beta}}
\end{aligned}
$$

Where $k_{l}$ is a cutpoint and $u_{j}$ is a random error, assumed to be logistically distributed. An independent variable with a positive coefficient contributes to higher category $l$ (in our model, a higher Standardized $\mathrm{BW}_{j}$ ). Coefficients are estimated using maximum likelihood. To identify statistically significant independent variables, stepwise (backward selection) at a significance level of $10 \%$ was applied. 


\section{Measuring the relative importance of resilience to other ecosystem services}

The relative importance of resilience to other ecosystem services could help decision makers anticipate responses to a resilience management. To measure relative importance, we prepared an original list of benefits from coral reef ecosystems, for three reasons (Table 3). First, generic classifications (MEA 2005, Böhnke-Henrichs et al. 2013, Hattam et al. 2015) might be less accessible for nonacademics, and more context-specific and concrete items are desirable. Second, resilience needs to be added. Third, following a recent discussion about the diversity of values, relational values (Chan et al. 2016, Klain et al. 2017, Pascual et al. 2017, Uehara et al. 2018) were also added. Relational values uncover the relationship between nature and people, not only to conserve nature, but also to provide benefits. We adopted a list of benefits for Japanese coral reef ecosystems from the Ministry of the Environment, Government of Japan (2017) as a base. "Ingredients for pharmaceuticals" in the original list was replaced with "resilient ecosystems conserving genetic resources." We believe that this replacement is reasonable because finding genetic resources for pharmaceuticals and others is highly uncertain compared with other benefits and depends on the state of the ecosystem, i.e., resilience. The original description does not reflect these crucial points.

Table 3. Benefits obtained from coral reef ecosystems. For a description of each benefit, see Appendix 4.

\begin{tabular}{ll}
\hline \hline Items & Benefits Obtained from Coral Reef Ecosystems \\
\hline 1 & Affluent fishing grounds \\
2 & Decorations and souvenirs \\
3 & Building materials \\
4 & Natural breakwaters \\
5 & Formation of lands \\
6 & Resilient ecosystems that conserve genetic resources \\
7 & Cultural formations: unique traditional events and festivals \\
8 & Training grounds \\
9 & Comforts and tourism resources \\
10 & Ornamental fish \\
11 & Formation of connectedness to nature and people \\
\hline
\end{tabular}

We adopted the BWS and calculated the Standardized $\mathrm{BW}_{i}$ (Equation 3) to measure the relative importance. Although discrete choice experiments can measure the relative importance of multiple ecosystem services along with WTP (Aizaki et al. 2015), they are not suitable for many ecosystem services. A partial profile choice experiment that elicits the relative importance of many ecosystem services could be promising but is still under development (Shoji, Tsuge, Kubo, et al. 2018, unpublished manuscript).

As mentioned above, we split the respondents into two groups. Before seeing the questionnaire, one group was asked for a CVM, which included a detailed description of resilience and its benefits. The other group was asked, after filling out the questionnaire, if they saw any difference before and after. Along with 11 types of benefits, their descriptions were provided (Appendix 4 for the full description), so that people who did not know about resilience learned what it meant. The benefits of resilience were described in the questionnaire as "Enhancing resilience could contribute to maintaining coral reef ecosystems under disturbances. It also raises the potentialities to conserve genetic resources that could lead to the development of new drugs in the future."

Each respondent answered 11 mutually exclusive combinations of the 5 items, out of 11 (Appendix 4). The combination conformed to a balanced, incomplete block design (Louviere et al. 2015).

\section{RESULTS}

Although only $7 \%$ of respondents both inside and outside Okinawa knew the meaning of resilience, $17 \%$ of them who work in the fishery in Okinawa or any industry related to sea, not the fishery, knew the meaning of resilience. They were less knowledgeable about genetic resources ( $5 \%$ outside Okinawa and $4 \%$ in Okinawa said yes). Recognition of the degradation of coral reef ecosystems in Okinawa, though, shows a stark contrast: $69 \%$ in Okinawa said yes, versus 39\% outside Okinawa. Further descriptive statistics are available in Appendix 1.

\section{Willingness to pay for benefits gained from resilience management}

Table 4 shows WTP estimates for the benefits expected from resilience management of coral reef ecosystems in Okinawa. WTP was estimated using simple logit models (Table 5). Following standard CVM practices (Freeman et al. 2014, Boyle 2017), respondents who said no to bid because they opposed some aspects of the scenario rather than its benefits, and respondents who said yes to bid because they valued spending money for public irrespective of the benefits, were dropped from the WTP estimate.

Table 4. Willingness to pay (WTP) estimates for residents inside and outside Okinawa.

\begin{tabular}{lccccc}
\hline \hline & \multicolumn{2}{c}{ Okinawa } & & \multicolumn{2}{c}{ Outside } \\
\cline { 2 - 3 } \cline { 5 - 6 } & Estimate & $95 \%$ CI & & Estimate & $95 \%$ CI \\
\hline $\begin{array}{l}\text { Mean (truncated at } \\
\text { the maximum bid) }\end{array}$ & 4064 & $\{3439 ; 4818\}$ & 4444 & $\{3906 ; 5663\}$ \\
Median & 1943 & $\{1615 ; 2318\}$ & 1887 & $\{1666 ; 2579\}$ \\
\hline
\end{tabular}

The $95 \%$ confidence intervals (CI) of inside and outside Okinawa overlap both the mean and median WTP, indicating no significant difference. However, mean and median WTP differ significantly in both regions.

Table 6 shows the reasons for saying yes to bid. Out of 523 respondents who answered the reasons for saying yes, $74 \%$ chose the lower probability of losing the ecosystem's structure and functions, and $51 \%$ chose the expectation of richer genetic resources. Thirty-five percent of respondents (182 respondents) chose both.

\section{Human values underlying resilience}

Figure 1 shows standardized $\mathrm{BW}_{\mathrm{i}}$ for human values associated with resilience. Motivations associated with resilience, i.e., human values, showed a similar pattern (Fig. 1). Whereas conservation (conformity, security, and tradition) and self-transcendence (benevolence and universalism) are roughly equally important, self-enhancement (achievement and power) and openness to change/self-enhancement (hedonism) are largely irrelevant as reasons for supporting resilience. Openness to change (selfdirection and achievement) received some support from respondents outside Okinawa. 
Table 5. Simple logit models for willingness to pay (WTP) estimates.

\begin{tabular}{|c|c|c|c|c|c|c|c|c|}
\hline \multirow[b]{2}{*}{ Variable } & \multicolumn{4}{|c|}{ Okinawa } & \multicolumn{4}{|c|}{ Outside } \\
\hline & Coefficient & Std. Error & $p$-Value & & Coefficient & Std. Error & $p$-Value & \\
\hline Constant & 9.289 & 0.657 & $<0.001$ & ***** & 8.193 & 0.628 & $<0.001$ & ***** \\
\hline $\log (\mathrm{Bid})$ & -1.227 & 0.085 & $<0.001$ & $* * * *$ & -1.073 & 0.080 & $<0.001$ & **** \\
\hline Log-likelihood & -346.454 & & & & -329.845 & & & \\
\hline AIC & 696.907 & & & & 663.691 & & & \\
\hline $\mathrm{BIC}$ & 704.104 & & & & 670.781 & & & \\
\hline $\mathrm{N}$ & 270 & & & & 256 & & & \\
\hline
\end{tabular}

Table 6. Reasons for bidding (multiple choices).

\begin{tabular}{lcc}
\hline \hline & $\begin{array}{c}\text { Frequency } \\
\text { age }\end{array}$ \\
\hline $\begin{array}{l}\text { Because the enhancement of coral reefs' resilience } \\
\text { lowers the probability of losing the ecosystem's }\end{array}$ & 386 & $74 \%$ \\
$\begin{array}{l}\text { structure and functions. } \\
\text { Because we expect richer genetic resources. }\end{array}$ & 267 & $51 \%$ \\
$\begin{array}{l}\text { Because it is beneficial to spend money on public } \\
\text { goods, regardless of the efficacy of resilience }\end{array}$ & 80 & $15 \%$ \\
management. & 48 & $9 \%$ \\
Other & & \\
\hline$N=523$ & & \\
\end{tabular}

Fig. 1. Standardized BWi for human values associated with resilience.

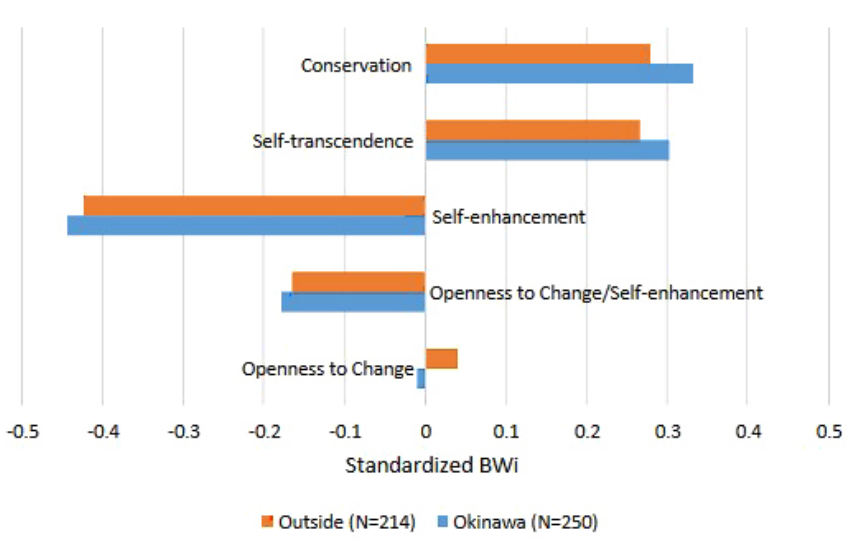

Ordered logit models for human values associated with resilience, i.e., conservation, self-transcendence, and openness to change, which explain respondents' attributes that support each value, showed stark contrasts (Table 7). Whereas conservation and selftranscendence were favored by females, openness to change was favored by males. In Okinawa, conservation and selftranscendence were not favored by fishermen, but openness to change was. Respondents knowledgeable about ecosystem degradation in Okinawa favored conservation.

\section{The relative importance of resilience}

Figure 2 shows the standardized $\mathrm{BW}_{\mathrm{i}}$ for human values associated with coral reef ecosystem services. As shown in this Figure, respondents living inside and outside Okinawa have similar preferences about the benefits from coral reef ecosystems. Resilience was very important relative to other benefits, placing second for respondents outside Okinawa, regardless of whether they were asked before or after a detailed description of resilience in the CVM questionnaire. Respondents in Okinawa placed resilience second after the CVM question and third before it.

Fig. 2. Standardized $\mathrm{BW}_{\mathrm{i}}$ for human values associated with coral reef ecosystem services. Outside_X and Okinawa_X are respondents who answered the questions before contingent valuation method.

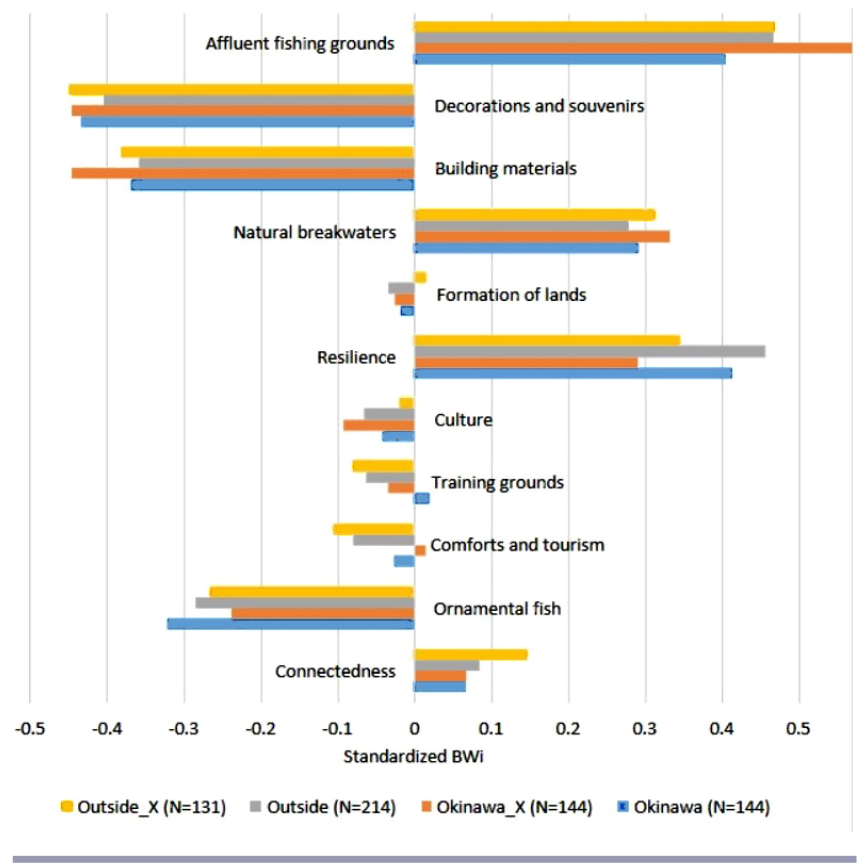

\section{DISCUSSION}

Because perception of resilience is our primary focus, it is critical to note that only $7 \%$ of respondents both inside and outside Okinawa knew the meaning of resilience. Because low recognition was expected, we designed the survey in a manner by which the respondents could learn the meaning of resilience during the survey. First, in the BWS questions, a description of resilience was provided, the same as for all the other ecosystem services (Table 4.2 in Appendix 4). Second, in the CVM, respondents took a quiz to check whether they understood the scenario and their 
Table 7. Ordered logit models with stepwise at 10\%.

\begin{tabular}{|c|c|c|c|c|c|c|}
\hline \multirow[b]{3}{*}{ Gender } & \multicolumn{2}{|c|}{ Conservation } & \multicolumn{2}{|c|}{ Self-Transcendence } & \multicolumn{2}{|c|}{ Openness to Change } \\
\hline & \multicolumn{2}{|c|}{ Coefficients } & \multicolumn{2}{|c|}{ Coefficients } & \multicolumn{2}{|c|}{ Coefficients } \\
\hline & $\begin{array}{l}-0.525 \\
(0.165)\end{array}$ & **** & $\begin{array}{l}-0.333 \\
(0.164)\end{array}$ & *** & $\begin{array}{c}0.418 \\
(0.166)\end{array}$ & ** \\
\hline Job (Fishermen in Okinawa) & $\begin{array}{l}-1.407 \\
(0.602)\end{array}$ & $* *$ & $\begin{array}{l}-1.504 \\
(0.638)\end{array}$ & $* *$ & $\begin{array}{l}1.157 \\
(0.603)\end{array}$ & * \\
\hline Knowledge about the degradation of coral reefs in Okinawa & $\begin{array}{c}0.519 \\
(0.166)\end{array}$ & $* * *$ & & & & \\
\hline Log-likelihood & -910.268 & & -905.839 & & -876.072 & \\
\hline LR chi2 & 24.52 & ${ }^{* * *}$ & 9.45 & $* * *$ & 9.15 & ${ }^{* *}$ \\
\hline Pseudo R2 & 0.0133 & & 0.005 & & 0.0054 & \\
\hline $\mathrm{N}$ & 464 & & 464 & & 464 & \\
\hline
\end{tabular}

benefits that include the understanding of resilience. Respondents who answered incorrectly were asked to reread the scenario before answering their WTP.

It should also be noted that the definition of resilience in this study is specific and narrower than its general definition (e.g., Holling et al. 2002). Because of the critical importance posed by the Aichi Biodiversity Target 13 (Convention on Biological Diversity 2010), the definition in this study focuses on genetic resources as a benefit of resilience management.

\section{The economic values of resilience}

Despite advances in the theoretical discussion of economic value of resilience (Perrings 1995, Holling et al. 2002, Baumgärtner 2007, Rönnbäck et al. 2007, Mäler 2008), there are insufficient empirical, particularly quantitative, studies. This study not only measured WTP for resilience but also elaborated on who values resilience for how much and what constitutes the WTP. Because the CVM scenario was designed as relevant and realistic as possible to science and policy, the findings could be readily informative for the resilience management of coral reef ecosystems. For example, the WTP in this study reflected respondents' subjective understanding of uncertainty regarding the effectiveness of resilience management.

No significant difference between the mean and median WTP was observed between inside and outside Okinawa. This result is reasonable because, in contrast to other ecosystem services, there is no assurance that residents in Okinawa benefit more from resilience management than residents outside of Okinawa. There is no difference in the amount of benefits from genetic resources obtained by people inside and outside Okinawa. Moreover, all the other ecosystem services such as fish, recreation, and aesthetic experience are assumed to remain the same in the scenario. Therefore, resilience management could be equally accepted and supported by the population, irrespective of their distance from the site.

The mean and median WTP significantly differed in both areas, indicating that the WTP distribution was skewed (Pearce et al. 2006). While a higher mean WTP was caused by giving more weight to a minority of respondents who provided strong support and a willingness to pay, the median WTP reflected what the majority of respondents were willing to pay (Pearce et al. 2006). It indicates that there exist some respondents with strong support and a willingness to pay for the resilience management and its benefits relative to the majority of respondents.

WTP estimates in our study ranged from about 1615 to 5663 JPY per respondent (Table 4). Because we found no comparable prior studies about how the WTP for resilience benefited from MPA for coral reef ecosystems, the absolute amounts of WTP, a direct comparison with previous research, is difficult to obtain. Studies about the WTP for MPA in coral reef ecosystems do exist, but they do not focus on resilience. One study estimated that the mean WTP for MPA for coral reef ecosystem services ranges from US\$3 to US\$27 per respondent (Kirkbride-Smith et al. 2016). However, for resilience management estimates to become more informative, a cost-benefit analysis (CBA) is crucial (Pascal et al. 2018). We did not conduct a CBA because of lack of data. This is a limitation of our study and a future research direction.

The theoretical discussion by Baumgärtner and Strunz (2014) noted that the economic value of resilience comprises two aspects: a lower probability of losing an ecosystem's structure and functions, and the expectation of richer genetic resources. The reasons for saying yes (Table 6) indicate that the respondents valued resilience because of these two aspects. However, not all respondents valued both of them; only $35 \%$ of respondents chose both. Also, our data was unable to test if they are additive, as argued in the theoretical discussion (Baumgärtner and Strunz 2014). To test this, a method that measures the substitutability of these two aspects, such as in a choice experiment (Holmes et al. 2017) could be used.

It should be emphasized that our study captured only a particular aspect of the value of resilience, in a specific context. We do not claim that our research captured all the elements of the value of resilience. Also, although our results could be used in a benefit transfer (Rosenberger and Loomis 2017), its practice and interpretation require careful consideration.

\section{Motivations for valuing resilience}

Whereas CVM does not consider motivation (Segerson 2017), HVT reveals it (Schwartz 2012). The BWS analysis of human values underlying resilience revealed that resilience was mainly 
supported by two value domains: self-transcendence (benevolence for family and neighbors, and universalism for human beings and for nature) and conservation (conformity: behaving respectfully, security: minimizing environmental impacts, and tradition: respect for local customs and traditions; Fig. 1). Openness to change (hedonism: the pure pleasure of discovery) was also a reason for respondents outside Okinawa (Fig. 1). A common theme in self-transcendence and conservation is the ability to move beyond oneself (Table 2). In other words, resilience was important because respondents valued selfrestraint and care for others, i.e., people, society, and nature. This finding is reasonable because the questionnaire emphasized to respondents the uncertainty of the direct benefits of genetic resources. These findings could help decision makers design resilience management. Individuals who prioritize selftranscendence values are likely to support collaborative approaches focusing on social benefits, and individuals who prioritize conservation are likely to support resilience management that maintains local traditions or practices (Hicks et al. 2015).

Respondents living outside Okinawa favored openness to change to some extent, which requires a different interpretation. They found resilience important because they valued the exploration of new sources of income, new genetic resources, the novelty of resilience thinking, and the challenge of uncertainty (Table 2). This could be due to fundamental differences in what human values respondents prioritize in their lives. It is also interesting to further investigate what social-ecological contexts influence their human value priorities.

The logit models in Table 7 showed the stark differences between these two groups regarding human values. Whereas Okinawa respondents not involved in the fishing business favored selftranscendence and conservation, those engaged in fishing favored openness to change. Coral reef ecosystems are an essential source of income for them, and they appreciated resilience because the ecosystems provided sources of income. For instance, fishermen could become involved in the collection of genetic resources, maintaining or increasing their income from ecosystems, even if fishing were restricted. Okinawa respondents were aware that coral reef ecosystem degradation favored conservation, implying that they supported resilience for the future of the environment.

Figure 3 extends the Schwartz value wheel with ecosystem services identified by Hicks et al. (2015), by adding resilience based on our study. The Schwartz value wheel is a central analytic tool of the HVT because it explains conflicts and compatibility among values (Schwartz 1996). Adjacent values are compatible, while values located on opposite sides are conflictual. For example, universalism and benevolence are compatible because they share the motivational interests of enhancement of others and transcendence over selfish interests (Schwartz 2012). Conversely, benevolence and achievement conflict because the former pursues transcendence of selfish interests, but the latter pursues these selfish interests. Figure 3 also shows what value domains and types are underlying preferences for ecosystem services. For example, according to the findings of Hicks et al. (2015), people favor "coastal protection, sanitation, \& habitat" because they value selftranscendence (benevolence and universalism). Along with the findings of Hicks et al. (2015), regarding underlying ecosystem services, we discuss resilience to other ecosystem services and their corresponding human values (Fig. 1).

Fig. 3. The Schwartz value wheel, including ecosystem services and resilience. The figure was adopted and modified based on Hicks et al. (2015), Schwartz (2012), and our findings.

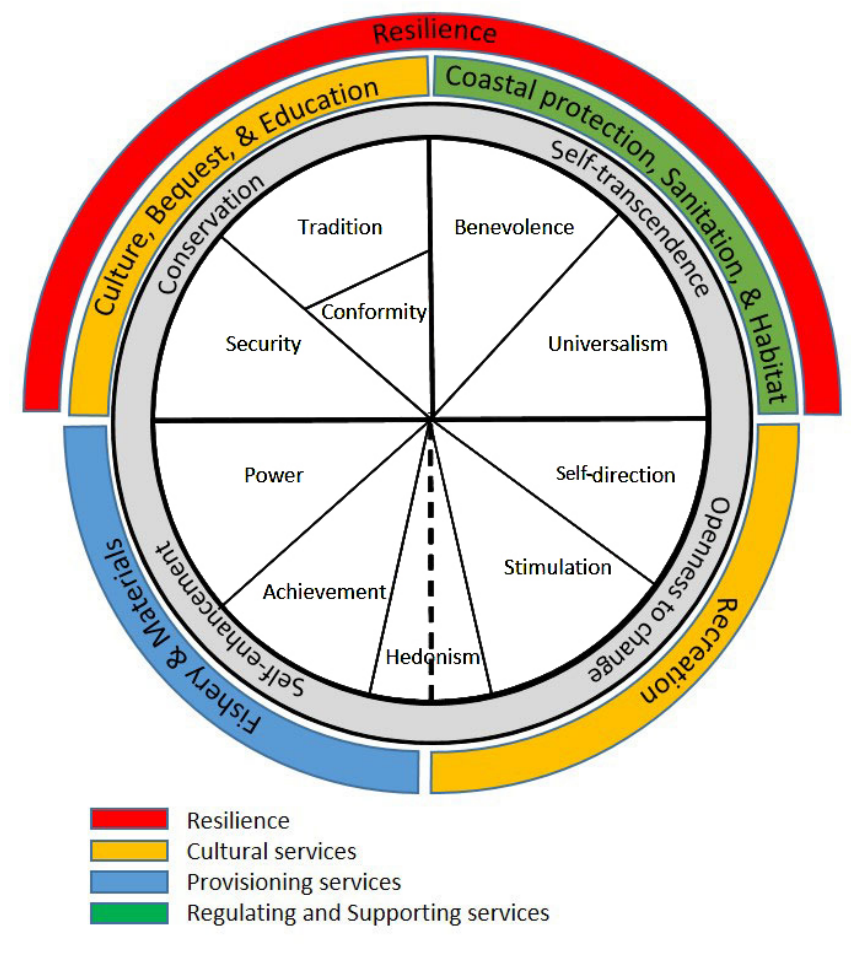

Figure 3 shows that resilience shares value domains with "culture, bequest, \& education" and "coastal protection, sanitation, \& habitat." However, there are several caveats. First, the value wheel was based on findings derived from different sites by Hicks et al. (2015). Additionally, Hicks et al. (2015) targeted fishermen. Last, our study used an online survey whereas Hicks et al.'s research conducted interviews.

In our research, resilience, compared with other ecosystem services studies, relates to a broader context beyond ecosystem management. Because human values govern not only how people respond to environmental concerns but also to other everyday decisions (Schwartz 1992, 2012), decision makers should see people's reactions in a broader context. It may be interesting to measure people's human values in general and then link our findings with them. They could provide interesting management implications.

\section{The relative importance of resilience}

Although HVT revealed the characteristics of resilience to values that motivate people's attitudes and behavior, the relative importance of resilience versus other ecosystem services using BWS directly measured this relative importance. To the best of our knowledge, no study has measured the relative importance of resilience. However, rankings of ecosystem services by Hicks et al. (2015) indicate that our results may be reasonable. Based on interviews and focus groups with workers in the fishing industry, 
four groups of services were ranked: (1) fishing, (2) habitat and education, (3) coastal protection, sanitation, and bequest, and (4) materials, recreation, and culture. Figure 2 shows a similar pattern. Although resilience was not measured by Hicks et al. (2015), their value wheel provides a clue. Ecosystem services such as habitat, education, coastal protection, sanitation, and bequest, which share the same value domains (conservation and self-transcendence) as resilience were ranked higher, but lower than fishing. Although resilience was rated high, it was lower than fishing in our study. We did not expect that respondents would rate resilience high before learning the importance of resilience in the CVM scenario (Outside_X and Okinawa_X in Fig. 2). Because the survey did not explain this aspect of resilience at the outset, no bias favoring resilience should be assumed. These findings help decision makers anticipate how people respond to resilience management and what form of resilience management is better accepted. What is interesting is that although most provisioning services, i.e., "decorations and souvenirs," "building materials," and "ornamental fish," can be given up for enhancing resilience, "affluent fishing grounds," which provide fish to eat, are in high demand. Although the former are either luxury or substitutable goods, the latter is a necessity and less easily substituted.

Another interesting point is that despite our expectations, there was no stark contrast in the relative importance between the respondents inside and outside Okinawa. For example, we expected that respondents inside Okinawa value natural breakwaters more than respondents outside Okinawa do, because they could face severer natural disasters without them. One interpretation is that respondents inside and outside Okinawa value each ecosystem service for different reasons. Although natural breakwaters are of practical importance for respondents inside Okinawa, they could be a moral issue for respondents outside Okinawa.

Last, this study measured the trade-offs and synergies of resilience from the demand side. For decision makers, it is critical to compare these demand-side views with supply-side trade-offs, i.e., what sacrifices regarding various ecosystem services does a resilience management have to make?

\section{CONCLUSION}

Our study helps alleviate a prior lack of academic studies about people's perceptions of resilience. Resilience management, which should be effective, acceptable, and supported, is not introduced in a vacuum but real contexts involving various interests. Therefore, for resilience management to enter mainstream ecosystem management, not only the quantifications of resilience as an attribute of SESs, e.g., thresholds and safe operating spaces, but also how people see resilience is integral. Analyzing coral reef ecosystems in Okinawa, Japan, we applied three distinct metrics: the value of resilience, motivations behind valuing resilience, and the relative importance of resilience versus other ecosystem services. These overlap but also complement each other and provide various management implications.

Our study revealed that ex-ante WTP for expected benefits from a resilience management program ranged from 3439 to 5663 JPY for mean WTP and from 1615 to 2579 JPY for median WTP (cf. 100 $\mathrm{JPY}=\mathrm{US} \$ 0.89$ in 2017). The primary motivations behind valuing resilience were conservation and self-transcendence. Overall, resilience is relatively important compared with the other coral ecosystem services with the exception of affluent fishing grounds.
Despite our expectations, there was not much difference in the three metrics of perceptions of resilience between respondents living inside and outside Okinawa except for their preferences for openness to change as a primary motivation behind valuing resilience.

There have been many studies on ecosystem services such as their economic valuation and trade-offs and synergies between them. However, the economic valuation focusing on resilience has been lacking. Also, resilience is not always an integral part of these studies, although there exist trade-offs and synergies between these ecosystem services and resilience. Our findings can be a direct input to resilience management, which is gaining more support as an effective ecosystem management (Bellwood et al. 2004, Nyström et al. 2008, Hughes et al. 2010, Anthony et al. 2015, Karr et al. 2015, Mellin et al. 2016).

Responses to this article can be read online at: http://www.ecologyandsociety.org/issues/responses. php/10903

\section{Acknowledgments:}

This study was funded by the Japanese Ministry of Environment (the policy studies of environmental economics (Phase 3, No.7)).

\section{LITERATURE CITED}

Aizaki, H., T. Nakatani, and K. Sato. 2015. Stated preference methods using R. Chapman and Hall/CRC, Boca Raton, Florida, USA. https://doi.org/10.1201/b17292

Anderies, J. M., B. H. Walker, and A. P. Kinzig. 2006. Fifteen weddings and a funeral: case studies and resilience-based management. Ecology and Society 11(1):21. https://doi. org/10.5751/ES-01690-110121

Anthony, K. R. N., P. A. Marshall, A. Abdulla, R. Beeden, C. Bergh, R. Black, C. M. Eakin, E. T. Game, M. Gooch, N. A. J. Graham, et al. 2015. Operationalizing resilience for adaptive coral reef management under global environmental change. Global Change Biology 21(1):48-61. https://doi.org/10.1111/gcb.12700

Arrieta, J. M., S. Arnaud-Haond, and C. M. Duarte. 2010. What lies underneath: conserving the oceans' genetic resources. Proceedings of the National Academy of Sciences 107 (43):18318-18324. https://doi.org/10.1073/pnas.0911897107

Arrow, K. J., P. Dasgupta, and K.-G. Mäler. 2003. Evaluating projects and assessing sustainable development in imperfect economies. Environmental and Resource Economics 26 (4):647-685. https://doi.org/10.1023/B:EARE.0000007353.78828.98

Baho, D. L., C. R. Allen, A. S. Garmestani, H. B. Fried-Petersen, S. E. Renes, L. Gunderson, and D. G. Angeler. 2017. A quantitative framework for assessing ecological resilience. Ecology and Society 22(3):17. https://doi.org/10.5751/ES-09427-220317

Baral, N., M. J. Stern, and R. Bhattarai. 2008. Contingent valuation of ecotourism in Annapurna conservation area, Nepal: implications for sustainable park finance and local development. Ecological Economics 66(2-3):218-227. https://doi.org/10.1016/j. ecolecon.2008.02.004 
Bartkowski, B., N. Lienhoop, and B. Hansjürgens. 2015. Capturing the complexity of biodiversity: a critical review of economic valuation studies of biological diversity. Ecological Economics 113:1-14. https://doi.org/10.1016/j.ecolecon.2015.02.023

Baumgärtner, S. 2007. The insurance value of biodiversity in the provision of ecosystem services. Natural Resource Modeling 20 (1):87-127. https://doi.org/10.1111/j.1939-7445.2007.tb00202.x

Baumgärtner, S., and S. Strunz. 2014. The economic insurance value of ecosystem resilience. Ecological Economics 101:21-32. https://doi.org/10.1016/j.ecolecon.2014.02.012

Bellwood, D. R., T. P. Hughes, C. Folke, and M. Nyström. 2004. Confronting the coral reef crisis. Nature 429:827-833. https://doi. org/10.1038/nature02691

Berkes, F., and C. Folke. 1998. Linking social and ecological systems for resilience and sustainability. Pages 13-20 in F. Berkes and C. Folke, editors. Linking social and ecological systems: management practices and social mechanisms for building resilience. Cambridge University Press, Cambridge, UK.

Biggs, R., M. Schlüter, and M. L. Schoon. 2015. Principles for building resilience: sustaining ecosystem services in socialecological systems. Cambridge University Press, Cambridge, UK. https://doi.org/10.1017/CBO9781316014240

Böhnke-Henrichs, A., C. Baulcomb, R. Koss, S. S. Hussain, and R. S. de Groot. 2013. Typology and indicators of ecosystem services for marine spatial planning and management. Journal of Environmental Management 130:135-145. https://doi.org/10.1016/ j.jenvman.2013.08.027

Boyle, K. J. 2017. Contingent valuation in practice. Pages 81-131 in P. A. Champ, K. J. Boyle, and T. C. Brown, editors. A primer on nonmarket valuation: the economics of non-market goods and resources. Kindle edition. Springer, Dordrecht, The Netherlands. https://doi.org/10.1007/978-94-007-7104-8 4

Brown, T. C. 1984. The concept of value in resource allocation. Land Economics 60(3):231-246. https://doi.org/10.2307/3146184

Carpenter, S., B. Walker, J. M. Anderies, and N. Abel. 2001. From metaphor to measurement: resilience of what to what? Ecosystems 4(8):765-781. https://doi.org/10.1007/s10021-001-0045-9

Chan, K. M. A., P. Balvanera, K. Benessaiah, M. Chapman, S. Díaz, E. Gómez-Baggethun, R. Gould, N. Hannahs, K. Jax, S. Klain, G. W. Luck, B. Martín-López, B. Muraca, B. Norton, K. Ott, U. Pascual, T. Satterfield, M. Tadaki, J. Taggart, and N. Turner. 2016. Opinion: why protect nature? Rethinking values and the environment. Proceedings of the National Academy of Sciences 113(6):1462-1465. https://doi.org/10.1073/pnas.1525002113

Convention on Biological Diversity. 2010. Aichi Biodiversity Targets. Convention on Biological Diversity, Montréal, Québec, Canada.

Cumming, G. S., and G. D. Peterson. 2017. Unifying research on social-ecological resilience and collapse. Trends in Ecology and Evolution 32(9):695-713. https://doi.org/10.1016/j.tree.2017.06.014

Erwin, P. M., S. López-Legentil, and P. W. Schuhmann. 2010. The pharmaceutical value of marine biodiversity for anti-cancer drug discovery. Ecological Economics 70(2):445-451. https://doi. org/10.1016/j.ecolecon.2010.09.030
Farnsworth, K. D., A. H. Adenuga, and R. S. de Groot. 2015. The complexity of biodiversity: a biological perspective on economic valuation. Ecological Economics 120:350-354. https:// doi.org/10.1016/j.ecolecon.2015.10.003

Flores, N. E. 2017. Conceptual framework for nonmarket Valuation. Pages 27-54 in P. A. Champ, K. J. Boyle, and T. C. Brown, editors. A primer on nonmarket valuation: the economics of non-market goods and resources. Kindle edition. Springer, Dordrecht, The Netherlands. https://doi.org/10.1007/978-94-007-7104-8_ 2

Folke, C., S. Carpenter, T. Elmqvist, L. Gunderson, C. S. Holling, and B. Walker. 2002. Resilience and sustainable development: building adaptive capacity in a world of transformations. $A M B I O$ 31(5):437-440. https://doi.org/10.1579/0044-7447-31.5.437

Freeman III, A. M., J. A. Herriges, and C. L. Kling. 2014. The measurement of environmental and resource values: theory and methods. Routledge, London, UK.

Fujikura, K., D. Lindsay, H. Kitazato, S. Nishida, and Y. Shirayama. 2010. Marine Biodiversity in Japanese Waters. PLoS ONE 5(8):e11836. https://doi.org/10.1371/journal.pone.0011836

Fujita, Y. 2003. Protest responses in contingent valuation method for coral reefs in Kerama Islands. Studies in Regional Science 34 (3):367-378. https://doi.org/10.2457/srs.34.3 367

Hattam, C., J. P. Atkins, N. Beaumont, T. Börger, A. BöhnkeHenrichs, D. Burdon, R. de Groot, E. Hoefnagel, P. A. L. D. Nunes, J. Piwowarczyk, S. Sastre, and M. C. Austen. 2015. Marine ecosystem services: linking indicators to their classification. Ecological Indicators 49:61-75. https://doi.org/10.1016/j. ecolind.2014.09.026

Hicks, C. C., J. E. Cinner, N. Stoeckl, and T. R. McClanahan. 2015. Linking ecosystem services and human-values theory. Conservation Biology 29(5):1471-1480. https://doi.org/10.1111/ cobi. 12550

Holling, C. S. 1973. Resilience and stability of ecological systems. Annual Review of Ecology and Systematics 4:1-23. https://doi. org/10.1146/annurev.es.04.110173.000245

Holling, C. S., S. R. Carpenter, W. A. Brock, and L. H. Gunderson. 2002. Discoveries for sustainable futures. Pages 395-418 in L. H. Gunderson and C. S. Holling, editors. Panarchy: understanding transformations in human and natural systems. Island Press, Washington, D.C., USA.

Holmes, T. P., W. L. Adamowicz, and F. Carlsson. 2017. Choice experiments. Pages 133-186 in P. A. Champ, K. J. Boyle, and T. C. Brown, editors. A primer on nonmarket valuation: the economics of non-market goods and resources. Kindle edition. Springer, Dordrecht, Netherlands. https://doi.org/10.1007/978-94-007-7104-8_5

Hughes, T. P., N. A. J. Graham, J. B. C. Jackson, P. J. Mumby, and R. S. Steneck. 2010. Rising to the challenge of sustaining coral reef resilience. Trends in Ecology \& Evolution 25(11):633-642. https://doi.org/10.1016/j.tree.2010.07.011

Karr, K. A., R. Fujita, B. S. Halpern, C. V. Kappel, L. Crowder, K. A. Selkoe, P. M. Alcolado, and D. Rader. 2015. Thresholds in Caribbean coral reefs: implications for ecosystem-based fishery management. Journal of Applied Ecology 52(2):402-412. https:// doi.org/10.1111/1365-2664.12388 
Kirkbride-Smith, A. E., P. M. Wheeler, and M. L. Johnson. 2016. Artificial reefs and marine protected areas: a study in willingness to pay to access Folkestone Marine Reserve, Barbados, West Indies. PeerJ 4:e2175. https://doi.org/10.7717/peerj.2175

Klain, S. C., P. Olmsted, K. M. A. Chan, and T. Satterfield. 2017. Relational values resonate broadly and differently than intrinsic or instrumental values, or the New Ecological Paradigm. PLoS ONE 12(8):e0183962. https://doi.org/10.1371/journal.pone.0183962

Krinsky, I., and A. L. Robb. 1986. On approximating the statistical properties of elasticities. Review of Economics and Statistics 68 (4):715-719. https://doi.org/10.2307/1924536

Kumar, P. 2010. The economics of ecosystems and biodiversity: ecological and economic foundations. Routledge, London, UK. https://doi.org/10.4324/9781849775489

Lee, J. A., G. Soutar, and J. Louviere. 2008. The best-worst scaling approach: an alternative to Schwartz's values survey. Journal of Personality Assessment 90(4):335-347. https://doi. org/10.1080/00223890802107925

Limburg, K. E., R. V. O'Neill, R. Costanza, and S. Farber. 2002. Complex systems and valuation. Ecological Economics 41 (3):409-420. https://doi.org/10.1016/S0921-8009(02)00090-3

Lindeman, M., and M. Verkasalo. 2005. Measuring values with the short Schwartz's value survey. Journal of Personality Assessment 85(2):170-178. https://doi.org/10.1207/s15327752jpa8502 09

Long, J. S., and J. Freese. 2014. Regression models for categorical dependent variables using Stata. Stata Press, College Station, Texas, USA.

Louviere, J. J., T. N. Flynn, and A. A. J. Marley. 2015. Best-worst scaling. Cambridge University Press, Cambridge, UK. https://doi. org/10.1017/CBO9781107337855

Mäler, K.-G. 2008. Sustainable development and resilience in ecosystems. Environmental and Resource Economics 39(1):17-24. https://doi.org/10.1007/s10640-007-9175-7

Mäler, K.-G., and C. Z. Li. 2010. Measuring sustainability under regime shift uncertainty: a resilience pricing approach. Environment and Development Economics 15(6):707-719. https:// doi.org/10.1017/S1355770X10000318

Mellin, C., M. A. MacNeil, A. J. Cheal, M. J. Emslie, and M. Julian Caley. 2016. Marine protected areas increase resilience among coral reef communities. Ecology Letters 19(6):629-637. https://doi.org/10.1111/ele.12598

Millennium Ecosystem Assessment (MEA). 2005. Ecosystems and human well-being: synthesis. Island Press, Washington, D. C., USA.

Ministry of the Environment, Government of Japan. 2017. The action plan to conserve coral reef ecosystems in Japan 2016-2020: to protect blessings from the coral sea.[Translated from the Japanese.] Ministry of the Environment, Tokyo, Japan. [online] URL: http://www.env.go.jp/press/files/jp/102644.pdf

Mitchell, R. C., and R. T. Carson. 1989. Using surveys to value public goods: the contingent valuation method. Resources for the Future, Washington, D.C., USA. https://doi.org/10.4324/9781315060569
Moberg, F. 2017. Feature/running out of reef resilience? Rethink, 30 March. [online] URL: https://rethink.earth/running-out-ofreef-resilience/

Moberg, F., and C. Folke. 1999. Ecological goods and services of coral reef ecosystems. Ecological Economics 29(2):215-233. https://doi.org/10.1016/S0921-8009(99)00009-9

Norström, A. V, M. Nyström, J.-B. Jouffray, C. Folke, N. A. J. Graham, F. Moberg, P. Olsson, and G. J. Williams. 2016. Guiding coral reef futures in the Anthropocene. Frontiers in Ecology and the Environment 14(9):490-498. https://doi.org/10.1002/fee.1427

Nyström, M., N. A. J. Graham, J. Lokrantz, and A. V Norström. 2008. Capturing the cornerstones of coral reef resilience: linking theory to practice. Coral Reefs 27(4):795-809. https://doi. org/10.1007/s00338-008-0426-Z

Oh, S. 2004. Economic valuation of Okinawa's coral reefs? Economic analysis of unavailable value by contingent valuable method. Journal of Business and Economics 32(2):35-54.

Pascal, N., A. Brathwaite, L. Brander, A. Seidl, M. Philip, and E. Clua. 2018. Evidence of economic benefits for public investment in MPAs. Ecosystem Services 30:3-13. https://doi.org/10.1016/j. ecoser.2017.10.017

Pascual, U., P. Balvanera, S. Díaz, G. Pataki, E. Roth, M. Stenseke, R. T. Watson, E. Başak Dessane, M. Islar, E. Kelemen, V. Maris, M. Quaas, S. M. Subramanian, H. Wittmer, A. Adlan, S. Ahn, Y. S. Al-Hafedh, E. Amankwah, S. T. Asah, P. Berry, A. Bilgin, S. J. Breslow, C. Bullock, D. Cáceres, H. Daly-Hassen, E. Figueroa, C. D. Golden, E. Gómez-Baggethun, D. GonzálezJiménez, J. Houdet, H. Keune, R. Kumar, K. Ma, P. H. May, A. Mead, P. O'Farrell, R. Pandit, W. Pengue, R. Pichis-Madruga, F. Popa, S. Preston, D. Pacheco-Balanza, H. Saarikoski, B. B. Strassburg, M. van den Belt, M. Verma, F. Wickson, and N. Yagi. 2017. Valuing nature's contributions to people: the IPBES approach. Current Opinion in Environmental Sustainability 26-27:7-16. https://doi.org/10.1016/j.cosust.2016.12.006

Pearce, D., G. Atkinson, and S. Mourato. 2006. Cost-benefit analysis and the environment: recent developments. Organisation for Economic Co-operation and Development, Paris, France.

Pearson, L. J., R. Biggs, M. Harris, and B. Walker. 2013. Measuring sustainable development: the promise and difficulties of implementing inclusive wealth in the Goulburn-Broken Catchment, Australia. Sustainability: Science, Practice and Policy 9(1):16-27. https://doi.org/10.1080/15487733.2013.11908104

Perrings, C. 1995. Biodiversity conservation as insurance. Pages 71-72 in T. Swanson, editor. The economics and ecology of biodiversity decline: the forces driving global change. Cambridge University Press, Cambridge, UK.

Perry, N., and S. Shankar. 2017. The state-contingent approach to the Noah's Ark problem. Ecological Economics 134:65-72. https://doi.org/10.1016/j.ecolecon.2016.12.002

Pritchard Jr, L., C. Folke, and L. Gunderson. 2000. Valuation of ecosystem services in institutional context. Ecosystems 3 (1):36-40. https://doi.org/10.1007/s100210000008

Quinlan, A. E., M. Berbés-Blázquez, L. J. Haider, and G. D. Peterson. 2015. Measuring and assessing resilience: broadening 
understanding through multiple disciplinary perspectives. Journal of Applied Ecology 53(3):677-687. https://doi.org/10.1111/1365-$\underline{2664.12550}$

Rockström, J., W. Steffen, K. Noone, Å. Persson, F. S. Chapin III, E. F. Lambin, T. M. Lenton, M. Scheffer, C. Folke, H. J. Schellnhuber, B. Nykvist, C. A. de Wit, T. Hughes, S. van der Leeuw, H. Rodhe, S. Sörlin, P. K. Snyder, R. Costanza, U. Svedin, M. Falkenmark, L. Karlberg, R. W. Corell, V. J. Fabry, J. Hansen, B. Walker, D. Liverman, K. Richardson, P. Crutzen, and J. A. Foley. 2009. A safe operating space for humanity. Nature 461 (7263):472-475. https://doi.org/10.1038/461472a

Rolfe, J., and J. Windle. 2015. Do respondents adjust their expected utility in the presence of an outcome certainty attribute in a choice experiment? Environmental and Resource Economics 60(1):125-142. https://doi.org/10.1007/s10640-014-9760-5

Rönnbäck, P., N. Kautsky, L. Pihl, M. Troell, T. Söderqvist, and H. Wennhage. 2007. Ecosystem goods and services from Swedish coastal habitats: identification, valuation, and implications of ecosystem shifts. AMBIO 36(7):534-544.

Rosenberger, R. S., and J. B. Loomis. 2017. Benefit transfer. Pages 445-482 in P. A. Champ, K. J. Boyle, and T. C. Brown, editors. $A$ primer on nonmarket valuation: the economics of non-market goods and resources. Kindle edition. Springer, Netherlands. https://doi. org/10.1007/978-94-007-0826-6_12

Schwartz, S. 1996. Value priorities and behavior: applying a theory of integrated value systems. Pages 1-24 in C. Seligman, J. M. Olson, and M. P. Zanna, editors. The psychology of values: the Ontario symposium, Vol. 8. Lawrence Erlbaum Associates Inc., Hillsdale, New Jersey, USA.

Schwartz, S. H. 1992. Universals in the content and structure of values: theoretical advances and empirical tests in 20 countries. Advances in Experimental Social Psychology 25:1-65. https://doi. org/10.1016/s0065-2601(08)60281-6

Schwartz, S. H. 2012. An overview of the Schwartz theory of basic values. Online Readings in Psychology and Culture 2(1):11. https://doi.org/10.9707/2307-0919.1116

Segerson, K. 2017. Valuing environmental goods and services: an economic perspective. Pages 1-25 in P. A. Champ, K. J. Boyle, and T. C. Brown, editors. A primer on nonmarket valuation: the economics of non-market goods and resources. Kindle edition. Springer, Netherlands. https://doi.org/10.1007/978-94-007-7104-8 1

Shinbo, T. 2007. Economic valuation of biodiversity in coral reef ocean: a case study of Kashiwa-island, Kochi. Journal of Rural Problems 43(1):42-47.

STATA. 2017. Stata base reference manual release 15. STATA Press, College Station, Texas, USA.

Sumaila, U. R., C. M. Rodriguez, M. Schultz, R. Sharma, T. D. Tyrrell, H. Masundire, A. Damodaran, M. Bellot-Rojas, R. M. P. Rosales, T. Y. Jung, V. Hickey, T. Solhaug, J. Vause, J. Ervin, S. Smith, and M. Rayment. 2017. Investments to reverse biodiversity loss are economically beneficial. Current Opinion in Environmental Sustainability 29:82-88. https://doi.org/10.1016/j. cosust.2018.01.007
Tamura, M. 2009. Coral reef ecosystem management towards its sustainable use: a questionnaire survey of socio-economic values of the ecosystem for Residents in Aka island. Journal of the Coral Reef Studies 11(1):9-22. [Translated from the Japanese.] https:// doi.org/10.3755/jers.11.9

The Economics of Ecosystems and Biodiversity (TEEB). 2010. The Economics of Ecosystems and Biodiversity. Ecological and economic foundations. Earthscan, London, UK.

Traill, L. W., C. J. A. Bradshaw, and B. W. Brook. 2007. Minimum viable population size: a meta-analysis of 30 years of published estimates. Biological Conservation 139(1-2):159-166. https://doi. org/10.1016/j.biocon.2007.06.011

Uehara, T. 2013. Ecological threshold and ecological economic threshold: implications from an ecological economic model with adaptation. Ecological Economics 93:374-384. https://doi. org/10.1016/j.ecolecon.2013.06.014

Uehara, T., R. Sakurai, and T. Tsuge. 2018. Cultivating relational values and sustaining socio-ecological production landscapes through ocean literacy: a study on Satoumi. Environment, Development and Sustainability 1-18. https://doi.org/10.1007/ $\underline{\text { s10668-018-0226-8 }}$

Voltaire, L. 2017. Pricing future nature reserves through contingent valuation data. Ecological Economics 135:66-75. https://doi.org/10.1016/j.ecolecon.2016.12.032

Walker, B., C. S. Holling, S. R. Carpenter, and A. Kinzig. 2004. Resilience, adaptability and transformability in social-ecological systems. Ecology and Society 9(2):5. https://doi.org/10.5751/ ES-00650-090205

Walker, B., L. Pearson, M. Harris, K.-G. Maler, C.-Z. Li, R. Biggs, and T. Baynes. 2010. Incorporating resilience in the assessment of inclusive wealth: an example from south east Australia. Environmental and Resource Economics 45(2):183-202. https:// doi.org/10.1007/s10640-009-9311-7

Walker, B., and D. Salt. 2006. Resilience thinking: sustaining ecosystems and people in a changing world. Island Press, Washington, D.C., USA. 
Appendix 1. Descriptive statistics.

Table A1.1 Residency of respondents

\begin{tabular}{l|rr} 
& Frequency & \multicolumn{2}{|c}{ Percent } \\
\hline Outside of Okinawa & 605 & $52 \%$ \\
Okinawa & 566 & $48 \%$ \\
\hline Total & 1171 & $100 \%$
\end{tabular}

Table A1.2 Have you been to or lived in Okinawa?

\begin{tabular}{l|rrr} 
& Frequency & \multicolumn{2}{c}{ Percent } \\
\hline Yes & 309 & $51 \%$ \\
No & 296 & $49 \%$ \\
\hline Total & 605 & $100 \%$
\end{tabular}

Table A1.3 Gender

\begin{tabular}{l|rr|r} 
& \multicolumn{1}{|c|}{ Male } & Female & \multicolumn{1}{c}{ Total } \\
\hline Outside of Okinawa & 331 & 274 & 605 \\
& $55 \%$ & $45 \%$ & $100 \%$ \\
Okinawa & 318 & 248 & 566 \\
& $56 \%$ & $44 \%$ & $100 \%$ \\
\hline Total & 649 & 522 & 1171 \\
& $55 \%$ & $45 \%$ & $100 \%$
\end{tabular}

Table A1.4 Age

\begin{tabular}{|c|c|c|c|c|c|c|}
\hline & $20 s$ & $30 \mathrm{~s}$ & $40 \mathrm{~s}$ & $50 \mathrm{~s}$ & $60 \mathrm{~s}$ & Total \\
\hline \multirow[t]{2}{*}{ Outside of Okinawa } & 88 & 141 & 126 & 127 & 123 & 605 \\
\hline & $15 \%$ & $23 \%$ & $21 \%$ & $21 \%$ & $20 \%$ & $100 \%$ \\
\hline \multirow[t]{2}{*}{ Okinawa } & 66 & 137 & 184 & 130 & 49 & 566 \\
\hline & $12 \%$ & $24 \%$ & $33 \%$ & $23 \%$ & $9 \%$ & $100 \%$ \\
\hline \multirow[t]{2}{*}{ Total } & 154 & 278 & 310 & 257 & 172 & 1171 \\
\hline & $13 \%$ & $24 \%$ & $26 \%$ & $22 \%$ & $15 \%$ & $100 \%$ \\
\hline
\end{tabular}

Table A1.5 Did you know the meaning of resilience?

\begin{tabular}{l|rrr|r} 
& Yes & \multicolumn{1}{c|}{ I have heard of it. } & No & \multicolumn{1}{c}{ Total } \\
\hline Outside of Okinawa & 42 & 104 & 459 & 605 \\
& $7 \%$ & $17 \%$ & $76 \%$ & $100 \%$ \\
Okinawa & 37 & 105 & 424 & 566 \\
& $7 \%$ & $19 \%$ & $75 \%$ & $100 \%$ \\
\hline Total & 79 & 209 & 883 & 1171
\end{tabular}




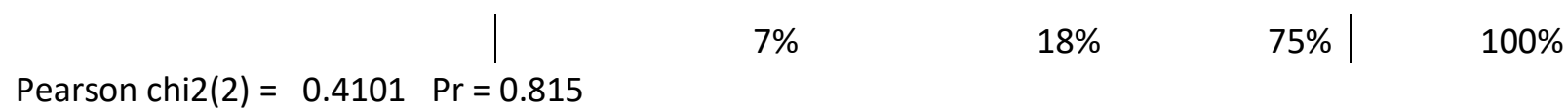

Table A1.6 Did you know the meaning of genetic resources?

\begin{tabular}{l|rrr|r} 
& Yes & \multicolumn{1}{c|}{ I have heard of it. } & No & \multicolumn{2}{c}{ Total } \\
\hline Outside of Okinawa & 33 & 64 & 508 & 605 \\
& & & & \\
\multirow{3}{*}{ Okinawa } & $5 \%$ & $11 \%$ & $84 \%$ & $100 \%$ \\
& 21 & 84 & 461 & 566 \\
\hline Total & $4 \%$ & $15 \%$ & $81 \%$ & $100 \%$ \\
\hline & 54 & 148 & 969 & 1171 \\
& $5 \%$ & $13 \%$ & $83 \%$ & $100 \%$
\end{tabular}

Pearson chi2(2) $=6.3572 \operatorname{Pr}=0.042$

Table A1.7 Did you know the coral reef ecosystems in Okinawa have been degraded?

\begin{tabular}{l|rrr|r} 
& \multicolumn{1}{|c}{ Yes } & I have heard of it. & \multicolumn{1}{c|}{ No } & \multicolumn{2}{c}{ Total } \\
\hline Outside of Okinawa & 237 & 243 & 125 & 605 \\
& $39 \%$ & $40 \%$ & $21 \%$ & $100 \%$ \\
Okinawa & 389 & 135 & 42 & 566 \\
& $69 \%$ & $24 \%$ & $7 \%$ & $100 \%$ \\
\hline Total & 626 & 378 & 167 & 1171 \\
& $53 \%$ & $32 \%$ & $14 \%$ & $100 \%$
\end{tabular}

Pearson chi2 $(2)=107.8367 \operatorname{Pr}=0.000$

Table A1.8 Do you think resilience is important?

\begin{tabular}{l|rr|r} 
& Yes & No & \multicolumn{1}{c}{ Total } \\
\hline Outside of Okinawa & 214 & 46 & 260 \\
Okinawa & $82 \%$ & $18 \%$ & $100 \%$ \\
& 250 & 28 & 278 \\
\hline Total & $90 \%$ & $10 \%$ & $100 \%$ \\
\hline & 464 & 74 & 538 \\
& $86 \%$ & $14 \%$ & $100 \%$
\end{tabular}

Pearson chi2 $(1)=6.5766 \operatorname{Pr}=0.010$

Table A1.9 Occupation (multiple choice)

\begin{tabular}{l|rrr|r} 
& Fishery in Okinawa & $\begin{array}{l}\text { Related to sea but not fishery in } \\
\text { Okinawa }\end{array}$ & Others & Total \\
\hline $\begin{array}{l}\text { Outside } \\
\text { of }\end{array}$ & & & & \\
Okinawa & 16 & 17 & 575 & 608 \\
Okinawa & 12 & 48 & 511 & 571 \\
\hline Total & 28 & 65 & 1086 &
\end{tabular}


Table A1.10 Income

\begin{tabular}{|c|c|c|c|}
\hline & $\begin{array}{c}\text { Outside of } \\
\text { Okinawa }\end{array}$ & Okinawa & Total \\
\hline \multirow[t]{2}{*}{2 million JPY or below } & 191 & 196 & 387 \\
\hline & $32 \%$ & $35 \%$ & $33 \%$ \\
\hline \multirow[t]{2}{*}{2 - 3 million JPY } & 107 & 122 & 229 \\
\hline & $18 \%$ & $22 \%$ & $20 \%$ \\
\hline \multirow[t]{2}{*}{4 - 5 million JPY } & 109 & 90 & 199 \\
\hline & $18 \%$ & $16 \%$ & $17 \%$ \\
\hline \multirow[t]{2}{*}{6 - 7 million JPY } & 49 & 26 & 75 \\
\hline & $8 \%$ & $5 \%$ & $6 \%$ \\
\hline \multirow[t]{2}{*}{8 - 9 million JPY } & 34 & 15 & 49 \\
\hline & $6 \%$ & $3 \%$ & $4 \%$ \\
\hline \multirow[t]{2}{*}{10 - 11 million JPY } & 16 & 9 & 25 \\
\hline & $3 \%$ & $2 \%$ & $2 \%$ \\
\hline \multirow[t]{2}{*}{12 - 13 million JPY } & 2 & 1 & 3 \\
\hline & $0 \%$ & $0 \%$ & $0 \%$ \\
\hline \multirow[t]{2}{*}{14 - 15 million JPY } & 6 & 2 & 8 \\
\hline & $1 \%$ & $0 \%$ & $1 \%$ \\
\hline \multirow[t]{2}{*}{16 million JPY or above } & 6 & 3 & 9 \\
\hline & $1 \%$ & $1 \%$ & $1 \%$ \\
\hline \multirow[t]{2}{*}{ n.a. } & 85 & 102 & 187 \\
\hline & $14 \%$ & $18 \%$ & $16 \%$ \\
\hline \multirow[t]{2}{*}{ Total } & 605 & 566 & 1171 \\
\hline & $100 \%$ & $100 \%$ & $100 \%$ \\
\hline
\end{tabular}

Table A1.11 Assume you can purchase an instant lottery that you could win 100,000 JPY with $50 \%$ chance of winning. Up to how much would you like to pay for the lottery?

\begin{tabular}{|c|c|c|c|}
\hline & Outside of Okinawa & Okinawa & Total \\
\hline \multirow[t]{2}{*}{0} & 64 & 61 & 125 \\
\hline & $11 \%$ & $11 \%$ & $11 \%$ \\
\hline \multirow[t]{2}{*}{10} & 146 & 121 & 267 \\
\hline & $24 \%$ & $21 \%$ & $23 \%$ \\
\hline \multirow[t]{2}{*}{2000} & 162 & 168 & 330 \\
\hline & $27 \%$ & $30 \%$ & $28 \%$ \\
\hline \multirow[t]{2}{*}{4000} & 77 & 77 & 154 \\
\hline & $13 \%$ & $14 \%$ & $13 \%$ \\
\hline \multirow[t]{2}{*}{8000} & 67 & 57 & 124 \\
\hline & $11 \%$ & $10 \%$ & $11 \%$ \\
\hline \multirow[t]{2}{*}{15000} & 28 & 28 & 56 \\
\hline & $5 \%$ & $5 \%$ & $5 \%$ \\
\hline 25000 & 24 & 24 & 48 \\
\hline
\end{tabular}




\begin{tabular}{|c|c|c|c|c|}
\hline \multirow{2}{*}{\multicolumn{2}{|c|}{35000}} & $4 \%$ & $4 \%$ & $4 \%$ \\
\hline & & 26 & 21 & 47 \\
\hline & \multirow{3}{*}{50000} & $4 \%$ & $4 \%$ & $4 \%$ \\
\hline & & 11 & 9 & 20 \\
\hline & & $2 \%$ & $2 \%$ & $2 \%$ \\
\hline \multirow[t]{2}{*}{ Total } & & 605 & 566 & 1,171 \\
\hline & & $100 \%$ & $100 \%$ & $100 \%$ \\
\hline
\end{tabular}


Appendix 2. Contingent valuation method.

\subsection{Hypothetical scenario for CVM}

We presented respondents the following hypothetical scenario.

Establish a $1 \mathrm{ha}(100 \mathrm{~m} \times 100 \mathrm{~m})$ of marine protected area (MPA) in coral reef ecosystems in Okinawa that enhance the resilience of the ecosystems and prevent from losing rich genetic resources. Although MPA could make various impacts, we assume that there is no impact other than resilience and genetic resources.

The maintenance of MPA requires costs for, for example, monitoring, removal of crown-of-thorns starfish, and transplanting coral reefs. Otherwise, MPA cannot be maintained.

We chose MPAs as resilience management measure because its effectiveness is well accepted in coral reef ecosystem management. For example, a study based on a 20 -year time series from Australia's Great Barrier Reef revealed that MPAs increased resilience (Mellin et al., 2016). Then, we articulated the benefits of the MPA, which contributes to respondents' utility.

The enhancement of coral reefs' resilience lowers the probability of losing the ecosystem structure and functions. Hence, we can expect richer genetic resources than other states (e.g., macro-algae, sea urchin barren, or rock dominant) where coral reef ecosystems are lost.

The benefits correspond with the two additive components of economic value of resilience (Baumgärtner and Strunz, 2014). Although MPAs could change other ecosystem services, we explained the respondents that other ecosystem services remain the same. Based on the experts' opinions, this assumption is not unrealistic at least. Since sampling for gene finding requires small amount of biomass, provisioning service of genetic resources does not involve threats to biodiversity (Arrieta et al., 2010).

Because uncertainty is critical of resilience and the discovery of genetic resources, we added the following two caveats regarding the benefits of the MPA.

Caveat 1: The discovery of genetic resources is not certain.

It is not certain when and what genetic resources are discovered in the established MPA. Furthermore, since it takes a long time (one to two decades) for a discovered genetic resource to be in practical use, it is not certain how much you can benefit from it.

Caveat 2: The efficacy of MPA for enhancing resilience is not certain.

While recent findings show the importance of MPA for resilience, it is not certain how much it can enhance resilience. It is also not uncertain how much vulnerable coral reef ecosystems become if they are not set as MPA. At the same time, it is extremely difficult to understand the complexity of coral reef ecosystems and to recover lost coral reef ecosystems. Hence, it may be necessary to manage the ecosystems even if it involves various uncertainties.

Images presented in the scenario to describe different states of coral reef ecosystems. 


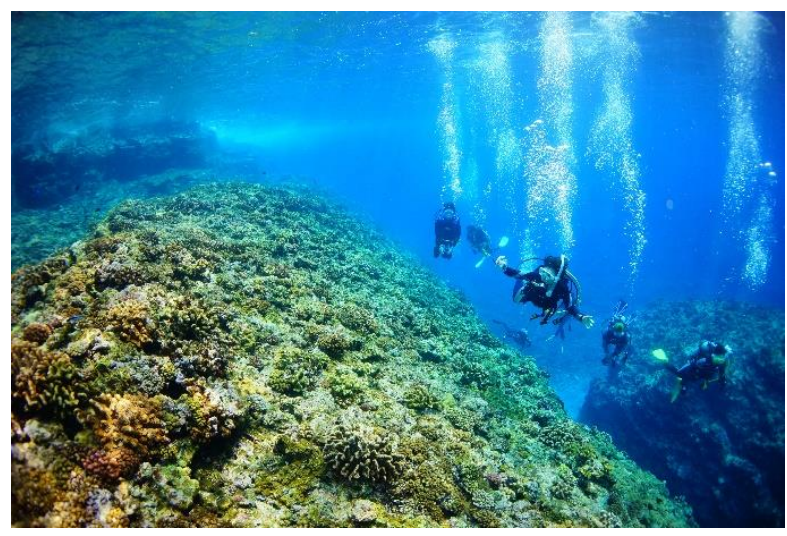

Healthy state

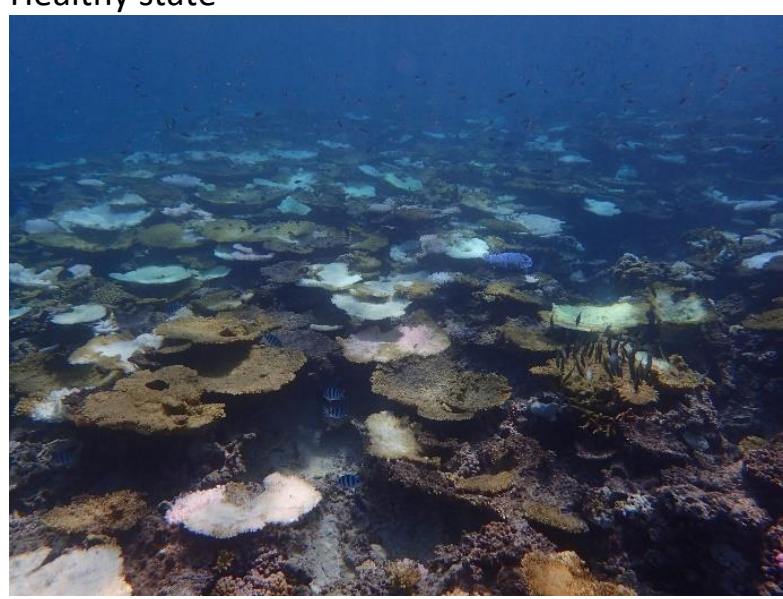

Bleached

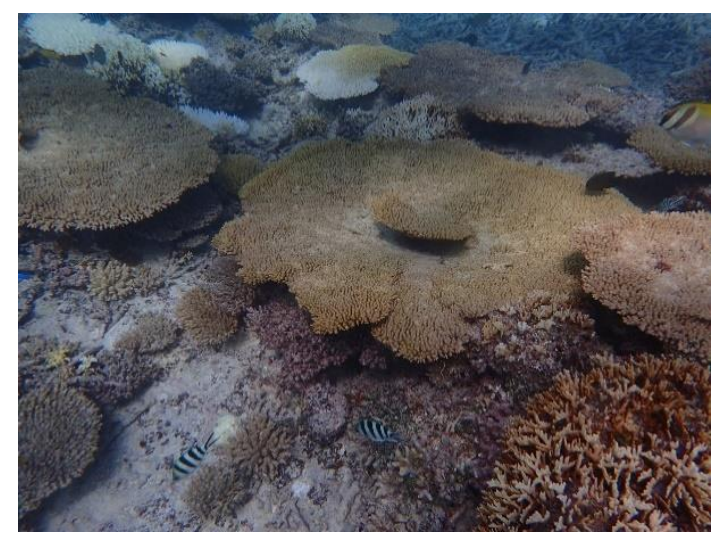

Covered with algae

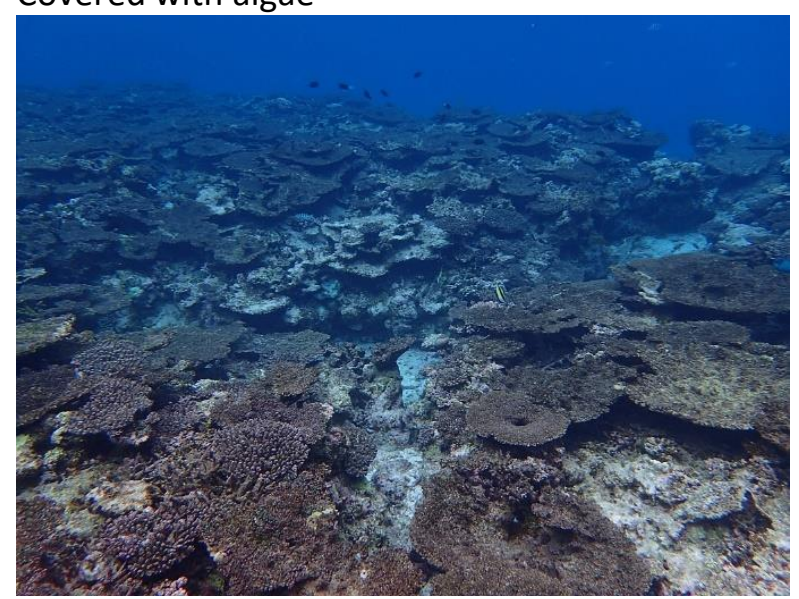

Dead

Pictures were provided by the Ministry of the Environment Government of Japan.

$2.2 \mathrm{~A}$ full model

Table A2.1 A full logit model to explore the factors affecting WTP estimates.

\begin{tabular}{lrrrl}
\hline Variable & Coefficient & Std. Error & $p$-Value & \\
\hline Constant & 7.235 & 0.669 & $<0.001$ & ${ }^{* * * *}$ \\
Gender & 0.191 & 0.204 & 0.348 & \\
Age & 0.258 & 0.077 & $<0.001$ & ${ }^{* * * *}$ \\
Knowledge of Resilience & 0.017 & 0.377 & 0.964 & \\
Knowledge of genetic & & & & \\
resources & 1.510 & 0.453 & $<0.001$ & ${ }^{* * * *}$ \\
Knowledge of coral reefs & 0.601 & 0.199 & 0.003 & ${ }^{* * *}$ \\
Job (Fishery in Okinawa) & 0.820 & 0.731 & 0.262 & \\
Job (Others in Okinawa) & -0.254 & 0.514 & $0.622^{*}$ & \\
Income & 0.175 & 0.062 & 0.005 & ${ }^{* * *}$ \\
log(Bid) & -1.249 & 0.067 & $<0.001$ & \\
\hline Log-likelihood & -564.500 & & &
\end{tabular}




\begin{tabular}{lc} 
AIC & 1149.000 \\
BIC & 1190.247 \\
$\mathrm{~N}$ & 457 \\
\hline$* * * * p<0.001,{ }^{* * *} p<0.01,{ }^{* *} p<0.05,{ }^{*} p<0.10$
\end{tabular}

Table A2.2 Description of variables used in the full logit model.

\begin{tabular}{llrr}
\hline Variable & Description & Mean & \multicolumn{1}{c}{ Std. Dev. } \\
\hline Gender & 1: Male, 2: Female & 1.446 & 0.497 \\
Age & 1: 10s, 2: 20s, .. 7: 70s or above & 4.013 & 1.254 \\
Knowledge of Resilience & 1: Knew, 0: Otherwise & 0.067 & 0.251 \\
Knowledge of genetic & 1: Knew, 0: Otherwise & 0.046 & 0.210 \\
resources & & & \\
Knowledge of coral reefs & 1: Knew, 0: Otherwise & 0.535 & 0.499 \\
Job (Fishery in Okinawa) & 1: Work in the fishery industry in Okinawa, 0: & 0.024 & 0.153 \\
& Otherwise & & \\
Job (Others in Okinawa) & 1: Work in Okinawa other than the fishery & 0.056 & 0.229 \\
& industry, 0: Otherwise & & \\
Income & 1: less than 2 million JPY, 2: 2-3 million JPY, ... 9: & 2.340 & 1.568 \\
& 16 million JPY or more. & & \\
\hline
\end{tabular}


Appendix 3. Human value theory.

Table A3.1 Combinations used in the BWS of the Human values underlying resilience

\begin{tabular}{|l|l|l|l|l|}
\hline & alt1 & alt2 & alt3 & alt4 \\
\hline set1 & 1 & 2 & 3 & 4 \\
\hline set2 & 1 & 3 & 4 & 5 \\
\hline set3 & 1 & 2 & 3 & 5 \\
\hline set4 & 1 & 2 & 4 & 5 \\
\hline set5 & 2 & 3 & 4 & 5 \\
\hline
\end{tabular}

1. Openness to change

2. Openness to change/ Self-

enhancement

3. Self enhancement

4. Self-transcendence

5. Conservation 
Appendix 4. Relative importance of resilience versus other ecosystem services.

Table A4.1 Combinations used in the BWS of the Ecosystem Services

\begin{tabular}{|l|r|r|r|r|r|}
\hline & alt1 & alt2 & alt3 & alt4 & \multicolumn{1}{l|}{ alt5 } \\
\hline set1 & 3 & 4 & 6 & 9 & 10 \\
\hline set2 & 2 & 5 & 6 & 8 & 9 \\
\hline set3 & 1 & 4 & 8 & 9 & 11 \\
\hline set4 & 1 & 3 & 5 & 8 & 10 \\
\hline set5 & 5 & 7 & 9 & 10 & 11 \\
\hline set6 & 1 & 2 & 3 & 7 & 9 \\
\hline set7 & 2 & 4 & 7 & 8 & 10 \\
\hline set8 & 3 & 6 & 7 & 8 & 11 \\
\hline set9 & 1 & 2 & 6 & 10 & 11 \\
\hline set10 & 1 & 4 & 5 & 6 & 7 \\
\hline set11 & 2 & 3 & 4 & 5 & 11 \\
\hline
\end{tabular}

1. Fishery

2. Crafts

3. Materials

4. Pier

5. Land

6. Resilience

7. Culture

8. Education

9. Tourism

10. Aquarium fish

11. Relationship

Table A4.2 List of coral reef ecosystem services. Respondents are presented "Benefits obtained from coral reef ecosystems" with corresponding "Description".

\begin{tabular}{|l|l|l|}
\hline No & $\begin{array}{l}\text { Benefits obtained } \\
\text { from coral reef } \\
\text { ecosystems }\end{array}$ & Description \\
\hline 1 & $\begin{array}{l}\text { Affluent fishing } \\
\text { grounds }\end{array}$ & $\begin{array}{l}\text { Coral reefs with extremely high productivity provide us with affluent } \\
\text { fishing grounds. One of the results of estimation indicates that fish and } \\
\text { shellfish unloaded from a coral reef of } 1 \mathrm{~km} 2 \text { would support the } \\
\text { livelihood of population of } 300 \text { or more. }\end{array}$ \\
\hline 2 & $\begin{array}{l}\text { Decorations and } \\
\text { souvenirs }\end{array}$ & $\begin{array}{l}\text { Organisms living in coral reefs are frequently utilized as decorative things } \\
\text { and also for ornamental purposes. In the Nansei Islands region, a variety }\end{array}$ \\
\hline
\end{tabular}




\begin{tabular}{|c|c|c|}
\hline & & $\begin{array}{l}\text { of accessories using shells of shellfish such as great green turbans are } \\
\text { manufactured and sold. }\end{array}$ \\
\hline 3 & Building materials & $\begin{array}{l}\text { In Okinawa and peripheral islands, coral reefs have provided materials } \\
\text { for buildings. For traditional buildings in this area, coral lime stone and } \\
\text { the coral population itself are used in many parts of buildings. For stone } \\
\text { walls in the Gusuku Sites and Related Properties of the Kingdom of } \\
\text { Ryukyu, registered as a world cultural heritage, lime stone is also used. }\end{array}$ \\
\hline 4 & $\begin{array}{l}\text { Natural } \\
\text { breakwaters }\end{array}$ & $\begin{array}{l}\text { It is reported that the tsunami due to the Sumatra-Andaman earthquake, } \\
2004 \text { was attenuated by the coral reef. Like this, coral reefs can bear the } \\
\text { role of a natural breakwater. The value of coral reefs in Okinawa } \\
\text { Prefecture as natural breakwaters was calculated as a trial and the result } \\
\text { reached up to } 55.9 \text { billion yen per a year. }\end{array}$ \\
\hline 5 & $\begin{array}{l}\text { Formation of } \\
\text { lands }\end{array}$ & $\begin{array}{l}\text { Occasionally, an island is formed due to the elevation of a coral reef. } \\
\text { Yoron Island and Kikaijima Island in the Amami Islands are good } \\
\text { examples. Further, skeletons of coral and shells of foraminifer living in } \\
\text { the coral reefs distribution zone are crushed to turn into sand and } \\
\text { contribute to the formation of islands. In such a way, coral reefs have } \\
\text { another function, to provide land. }\end{array}$ \\
\hline 6 & $\begin{array}{l}\text { Resilient } \\
\text { ecosystems } \\
\text { conserving } \\
\text { genetic resources }\end{array}$ & $\begin{array}{l}\text { Enhancing resilience could contribute to maintaining coral reef } \\
\text { ecosystems under disturbances. It also raises the potentialities to } \\
\text { conserve genetic resources that could lead to the development of new } \\
\text { drugs in the future. }\end{array}$ \\
\hline 7 & $\begin{array}{l}\text { Culture formation } \\
\text { - unique } \\
\text { traditional events } \\
\text { and festivals }\end{array}$ & $\begin{array}{l}\text { Islands in an area where coral reefs are distributed have many cultural } \\
\text { and traditional events derived from coral reefs. For example, in Okinawa, } \\
\text { there is a custom to hang shells of spider conch, which is a shellfish living } \\
\text { in a coral reef, from the eaves. }\end{array}$ \\
\hline 8 & Training grounds & $\begin{array}{l}\text { Coral reefs provide a ground for nature education activities in the region. } \\
\text { They are functioning as training grounds and provide many types of } \\
\text { teaching materials. }\end{array}$ \\
\hline 9 & $\begin{array}{l}\text { Comforts and } \\
\text { tourism resources }\end{array}$ & $\begin{array}{l}\text { We can enjoy the great variety of scenery of colorful and beautiful coral } \\
\text { reefs. Such a beautiful seascape of coral reefs has a great value as a } \\
\text { tourism resource. }\end{array}$ \\
\hline 10 & Ornamental fish & $\begin{array}{l}\text { Colorful fish living in a coral reef area are popular as ornamental fish. } \\
\text { Many types of ornamental fish are traded these days. }\end{array}$ \\
\hline 11 & $\begin{array}{l}\text { Connectedness to } \\
\text { nature and people }\end{array}$ & $\begin{array}{l}\text { Contact with coral reef ecosystems such as conservation activities could } \\
\text { form the relationship between the ecosystems and people. }\end{array}$ \\
\hline
\end{tabular}

